\title{
ENHANCEMENT OF STRUCTURAL FOAM MATERIALS BY INCORPORATION OF GASIFIER SLAG
}

\author{
Final Scientific/Technical Report
}

\author{
Reporting period start date: 01 October 2004 \\ Reporting period end date: 15 December 2005 \\ Principal Authors: Olin Perry Norton * \\ Ronald A. Palmer * \\ W. Gene Ramsey ${ }^{\dagger}$ \\ Date report issued: $\quad 15$ March 2006 \\ DOE. Award Number: $\quad$ DE-FC26-04NT42204 \\ Submitting organizations: * Institute for Clean Energy Technology (ICET) \\ Mississippi State University \\ 205 Research Boulevard \\ Starkville, Mississippi 39759 \\ $\dagger$ Earthstone International, LLC \\ 555 Republic Dr., Suite 440 \\ Plano, Texas 75074
}




\section{DISCLAIMER}

This report was prepared as an account of work sponsored by an agency of the United States Government. Neither the United States Government nor any agency thereof, nor any of their employees, makes any warranty, express or implied, or assumes any legal liability or responsibility for the accuracy, completeness, or usefulness of any information, apparatus, product, or process disclosed, or represents that its use would not infringe privately owned rights. Reference herein to any specific commercial product, process, or service by trade name, trademark, manufacturer, or otherwise does not necessarily constitute or imply its endorsement, recommendation, or favoring by the United States Government or any agency thereof. The views and opinions of authors expressed herein do not necessarily state or reflect those of the United States Government or any agency thereof. 


\begin{abstract}
As advanced gasification technology is increasingly adopted as an energy source, disposal of the resulting slag will become a problem. We have shown that gasifier slag can be incorporated into foamed glass, which is currently being manufactured as an abrasive and as an insulating material. The slag we add to foamed glass does not simply act as filler, but improves the mechanical properties of the product. Incorporation of gasifier slag can make foamed glass stronger and more abrasion resistant.
\end{abstract}




\section{TABLE OF CONTENTS}

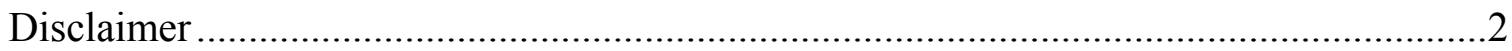

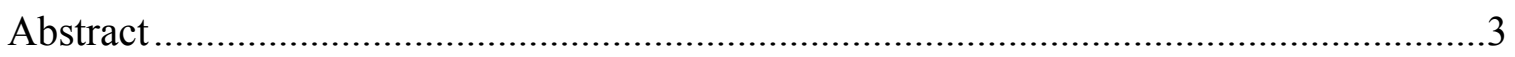

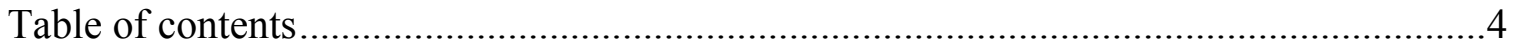

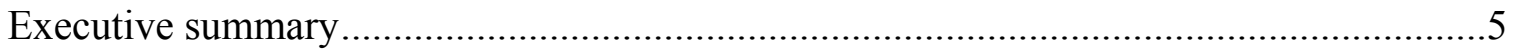

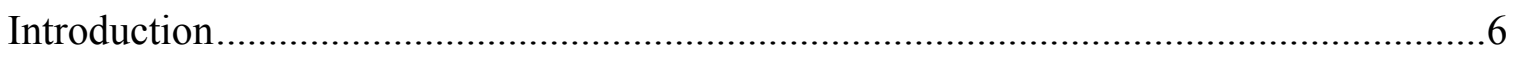

Phase 1. Optimization of slag content in foamed materials .........................................

Task 1. Determine maximum loading of slag content in foamed materials ......................8

Task 2. Determine limitations of foaming agents in the temperature range of

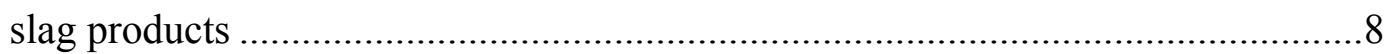

Phase 2. Evaluation of material properties of slag foams........................................ 18

Task 1. Evaluate shear strength, tensile strength, and modulus of rupture ......................18

Task 2. Determine ration of closed cell to open cell material in the foam slag.................31

Task 3. Evaluate health and safety implications of foaming agent / slag

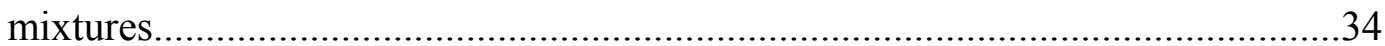

Task 4. Measure abrasion resistance, thermal conductivity, and softening point..............38

Task 5. Abrasive and adhesive properties of foam slag will be tested ..........................42

Phase 3. Quantification of slag foam process economics .............................................43

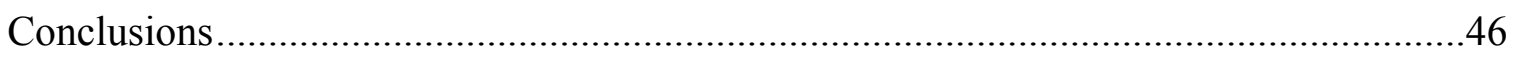

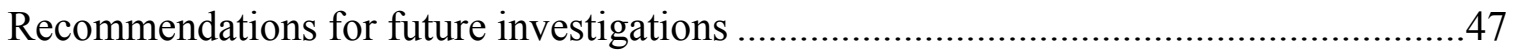

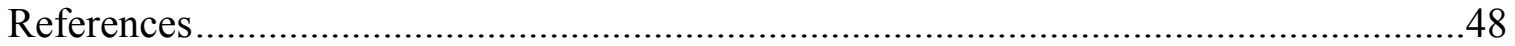

Appendix A. Equilibrium calculation of the thermal decomposition of calcium carbonate 


\section{EXECUTIVE SUMMARY}

The primary objective of this project is to incorporate the slag from IGCC (Integrated Gasification Combined Cycle) power plants as an ingredient in foamed glass. Success in achieving this objective would:

- $\quad$ Reduce the need to dispose of slag in a landfill.

- $\quad$ Reduce the cost of producing foamed glass.

- $\quad$ Add desirable color to the foamed glass product.

- Improve material properties such as hardness, abrasion resistance, and strength.

The project was divided into three phases. Phase 1 examined the optimization of slag content in the foamed glass. We determined the maximum loading of slag in a foamable product and the limitations of foaming agents over the temperature range of interest.

During Phase 2, the material properties of the slag foams were determined. These included tensile and compressive strength, the characterization of the porosity in the foams (open versus closed cells), an evaluation of the health and safety implications of foaming agent and slag mixtures, the abrasion resistance, thermal conductivity, and softening point of the materials, as well as the abrasive and adhesive properties of finished product.

Phase 3 was an evaluation of the overall economics of the process and the final product. We evaluated the slag foam production cost (including cost impact of slag incorporation versus current industrial practice), the impact of the inclusion of slag on foam production process, and the slag proximity to foam production locations and relative comminution cost of slag.

Our partner in this project, Earthstone International, is a commercial manufacturer of foamed glass products, and currently markets foamed glass as an abrasive. This project has demonstrated a significant increase in the abrasion resistance of the foamed glass product and a moderate increase in mechanical strength due to the incorporation of a small amount of gasifier slag. This will enable Earthstone to dramatically improve their abrasive products, with no increase in production costs. Although this application does not require a large amount of the waste material, the slag-reinforced foamed glass is a significant improvement over the base material. The improved material properties could also create additional markets for foamed glass, such as insulation for buildings. The additional ruggedness of the foamed glass will allow the manufacture of monolithic pieces of appropriate size for insulating walls of (for instance) houses.

Future work on this system could develop stronger materials and thus lead to wider applications. We have already been approached by a potential customer looking to use the stronger foamed glass product as a part of a system of protective armor. The brittle fracture of the foamed glass provides an energy absorbing barrier that can ameliorate the impact of rocket propelled grenades and other similar weapons. The success of the current project bodes well for this and other potential applications. 


\section{Introduction}

This project is being performed by the Institute for Clean Energy Technology (ICET), a unit of the Bagley College of Engineering at Mississippi State University. ICET was known as the Diagnostic Instrumentation and Analysis Laboratory (DIAL) prior to our name change in January of 2006. This project was performed in association with Earthstone International, a commercial manufacturer of foamed glass products. Earthstone currently markets foamed glass products as abrasives.

The primary objective of this project is to incorporate the slag from IGCC (Integrated Gasification Combined Cycle) power plants as an ingredient in foamed glass. Success in achieving this objective would:

- Reduce the need to dispose of slag in a landfill.

- Reduce the cost of producing foamed glass.

- Add desirable color to the foamed glass product.

- Improve material properties such as hardness, abrasion resistance, and strength.

Foamed glass is made by mixing finely ground glass with a foaming agent, together with colorants and other additives, and heating the mixture (called "batch") in a furnace. As the glass is heated to 700 to $900{ }^{\circ} \mathrm{C}\left(1300\right.$ to $\left.1650{ }^{\circ} \mathrm{F}\right)$, it begins to soften and form a highly viscous liquid. The foaming agent then releases gas, and the gas bubbles cause the glass to foam, expanding to several times its original volume. After cooling, the foamed glass looks like an ordinary kitchen sponge, consisting mostly of gas-filled voids separated by thin walls of glass. Unlike a sponge, foamed glass is very rigid. Foamed glass can be made with either a closed-cell foam structure or an open-cell foam structure.

In addition to its uses as an abrasive, foamed glass has many properties that would recommend it as a building material:

- Excellent insulating properties, which do not degrade with time. (PittsburghCorning markets a product, Foamglas ${ }^{\circledR}$, primarily as insulation for use in chemical plants and refineries.)

- Fireproof, and does not release any toxic fumes when heated.

- Does not mold, mildew, or rot, and is not eaten by insects or other vermin.

- Glass is one of the most chemically inert substances known.

- Can be produced cheaply.

- Can be made from recycled glass.

- Requires much less energy to produce than does expanded polystyrene.

Samples of IGCC gasifier slag were obtained from two sources: the Wabash River Project, operated by Global Energy, and Polk Power Station unit number 1, operated by Tampa Electric Company (TECO). The Wabash plant is fueled by petroleum coke, and the Tampa plant is fueled by a mixture of $55 \%$ petroleum coke and $45 \%$ coal. 
When the proposal was written for this work, we erroneously believed that the sample of Wabash slag sent to us by Global Energy was from the Kentucky Pioneer IGCC plant. Hence, the identification of this material in the original proposal was incorrect.

DOE suggests that this report be organized to first discuss experimental methods, and then discuss results and conclusions. We have adopted an alternate system of organization. Our reason for doing so is that we have used a number of disparate techniques to characterize different properties of the slag and foamed glass. If we first discuss all the testing techniques we used, and then all the results, the discussion of the results would be separated from the description of the testing method. So, we will first describe a testing method, and then the results obtained from that method, loosely organized according to the work breakdown structure. 


\section{Phase 1. Optimization of Slag Content in Foamed Materials}

Task 1. Determine maximum loading of slag in a foamable product.

Approach: This task was approached experimentally. These tests have been carried out in small batches in laboratory-scale, electrically heated furnaces at DIAL. At Earthstone, tests have been performed using the full-scale saggers used for commercial foamed glass production, which measure 0.349 by 0.491 meters (13-3/4 by 19-3/4 inches). Varying amounts of finely ground Wabash and Tampa slags were added to Earthstone's drywall batch. By a process of trial-and-error, we determined the maximum amount of each slag that could be added and still produce foamed glass.

(Note: "Batch" refers to the powdered mixture which is placed into the furnace for foaming, consisting of ground glass, foaming agent, and colorants and other additives. "Drywall" refers to an Earthstone foamed glass product is sold as an abrasive for finishing drywall. Hence "drywall batch" is the batch mixture that Earthstone uses to produce this product.)

Results: With Wabash slag, a maximum loading of approximately 7 per cent by weight (plus or minus 2 per cent) could be achieved. For the Tampa slag, the maximum loading we can achieve is about 3 per cent by weight.

Interestingly, the effect of adding Wabash slag is to increase the size of the pores in the product, whereas the Tampa slag seems to make the pores smaller. We do not currently understand the reason for this difference.

Based on the better results obtained with the Wabash slag, our efforts in the subsequent phases of this project focused on foamed glass made from the Wabash slag.

Task 2 Determine limitations of foaming agents in the temperature range of slag products.

Approach: The most important factor in foaming glass is to match the temperature of decomposition of the foaming agent to the temperature where the glass softens. Initially, the glass is a ground powder, which is porous. If the foaming agent decomposes and releases gas before the glass has started to soften, these gases can freely pass through the interstices between the glass particles and escape. Once the glass has started to soften and fuse, then the gases released will be trapped, and form bubbles. However, if the molten glass is too hot, the glass will not be viscous enough, and the gas bubbles can rise through the liquid glass and escape in that way. Thus, production of foam glass depends on matching the temperature range over which the foaming agent releases gas to the temperature range where the glass starts to behave as a liquid, but is still very viscous. Both of these temperature ranges can possibly be identified through DSC analyses of the foaming agent and glass, performed separately. 
When we wrote our original proposal, we believed that our thermal analysis instruments (DSC, TGA and DTA) would provide useful information regarding the decomposition of foaming agents and the softening temperatures of the glass frit and slag. DIAL's analytical laboratory contains a Netzsch Pegasus 404 DSC (Differential Scanning Calorimeter) with a platinum furnace. The temperature range of this instrument is from room temperature to $1500^{\circ} \mathrm{C}$. The laboratory also contains a Perkin-Elmer TG/DTA 6300 with a temperature range from room temperature to $1500^{\circ} \mathrm{C}\left(2730^{\circ} \mathrm{F}\right)$. (TG=Thermal Gravimetric and DTA=Differential Thermal Analyzer.)

The thermal gravimetric analyzer measures the mass of a sample with a sensitive balance as the sample is heated. Typically, the mass of a sample will decrease as the sample temperature increases. This mass loss can be due to the evaporation of water and other liquids, absorption and desorption, combustion, and thermal decomposition reactions that evolve gases.

DSC and DTA analyzers measure the amount of heat required to increase the temperature of the sample. This also reveals evaporation of water and other liquids (due to the latent heat of vaporization of the liquid), combustion (due to the heat released), and thermal decomposition reactions (which are usually endothermic). DSC and DTA results can also indicate phase changes and glass transitions. [1]

The difference between DSC and DTA is slight. DTA measures the small temperature difference between the sample and an inert reference material while both are being heated. This temperature difference is the output of the instrument. In DSC, the heating applied to the cooler of the two is increased to make both the same temperature, and the output of the instrument is the amount of differential heating required.

Results: Figures 1 through 7 show DSC results (thermograms) for the foaming agent, batch mixture, slag, and mixtures of these materials. These thermograms depict the behavior of the sample as it is heated (linear ramp) from ambient to a maximum temperature of 800 to $900{ }^{\circ} \mathrm{C}\left(1470\right.$ to $\left.1650^{\circ} \mathrm{F}\right)$. For these thermograms, the instrument output is not given in energy units, such as Watts per milligram, instead, the raw detector output in microvolts, normalized by the mass of the sample in milligrams, is plotted as a function of temperature. The sign of the detector output is such that an exothermic process produces a negative (downward) voltage, and an endothermic process produces a positive (upward) voltage.

An exothermic process, such as combustion, will thus appear as a downward peak in a DSC thermogram. Endothermic processes, such as thermal decomposition, melting, and driving off hydrated water or free water, will appear as an upward peak. According to Scherer [1], the glass transition temperature in a glass sample can be identified as a change in the slope of the thermogram. 


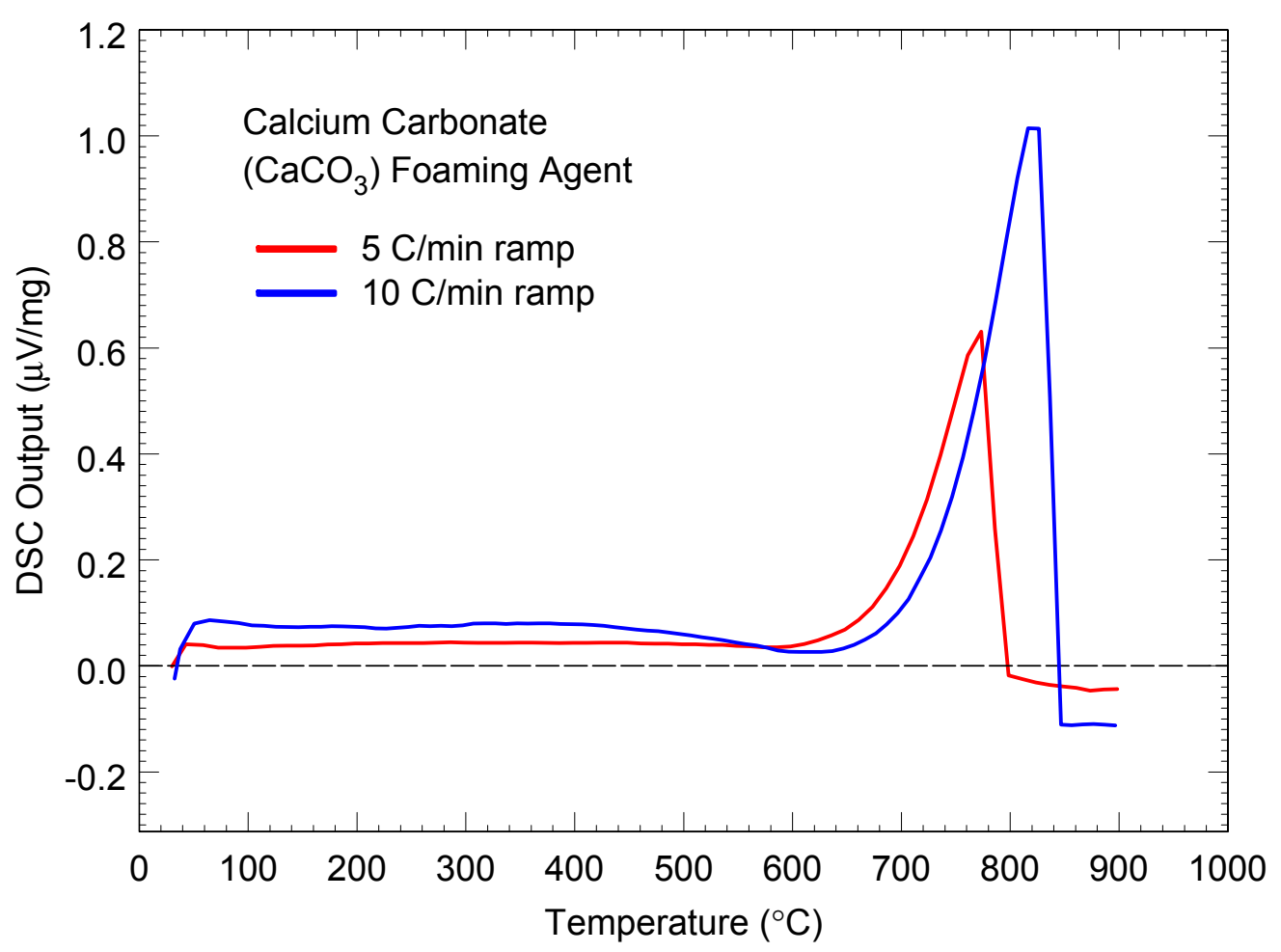

Figure 1. The thermal decomposition of the foaming agent, limestone ( $\left.\mathrm{CaCO}_{3}\right)$, to produce gaseous carbon dioxide is responsible for foaming. This figure shows DSC (Differential Scanning Calorimeter) results for limestone samples received from Earthstone. The vertical axis of the figure is oriented such that endothermic reactions produce an upward peak, and exothermic reactions produce a downward peak. The horizontal axis shows the temperature where the reaction occurs.

In the DCS instrument, the temperature starts at room temperature, and typically is ramped linearly at a constant rate of increase until the temperature maximum is reached. The two curves shown in this figure are the results of two separate runs with different ramp rates, $5{ }^{\circ} \mathrm{C}$ per minute and $10{ }^{\circ} \mathrm{C}$ per minute. At $5{ }^{\circ} \mathrm{C}$ per minute, the maximum rate of decomposition occurs at $760{ }^{\circ} \mathrm{C}$, whereas at $10{ }^{\circ} \mathrm{C}$ per minute, the maximum rate of decomposition occurs at $810{ }^{\circ} \mathrm{C}$. The atmosphere surrounding the sample was air in both cases.

The difference indicates that the reaction is not at equilibrium, and the kinetics of the reaction are important. This can also be seen by comparing these results to the equilibrium calculations reported in Appendix $A$. 


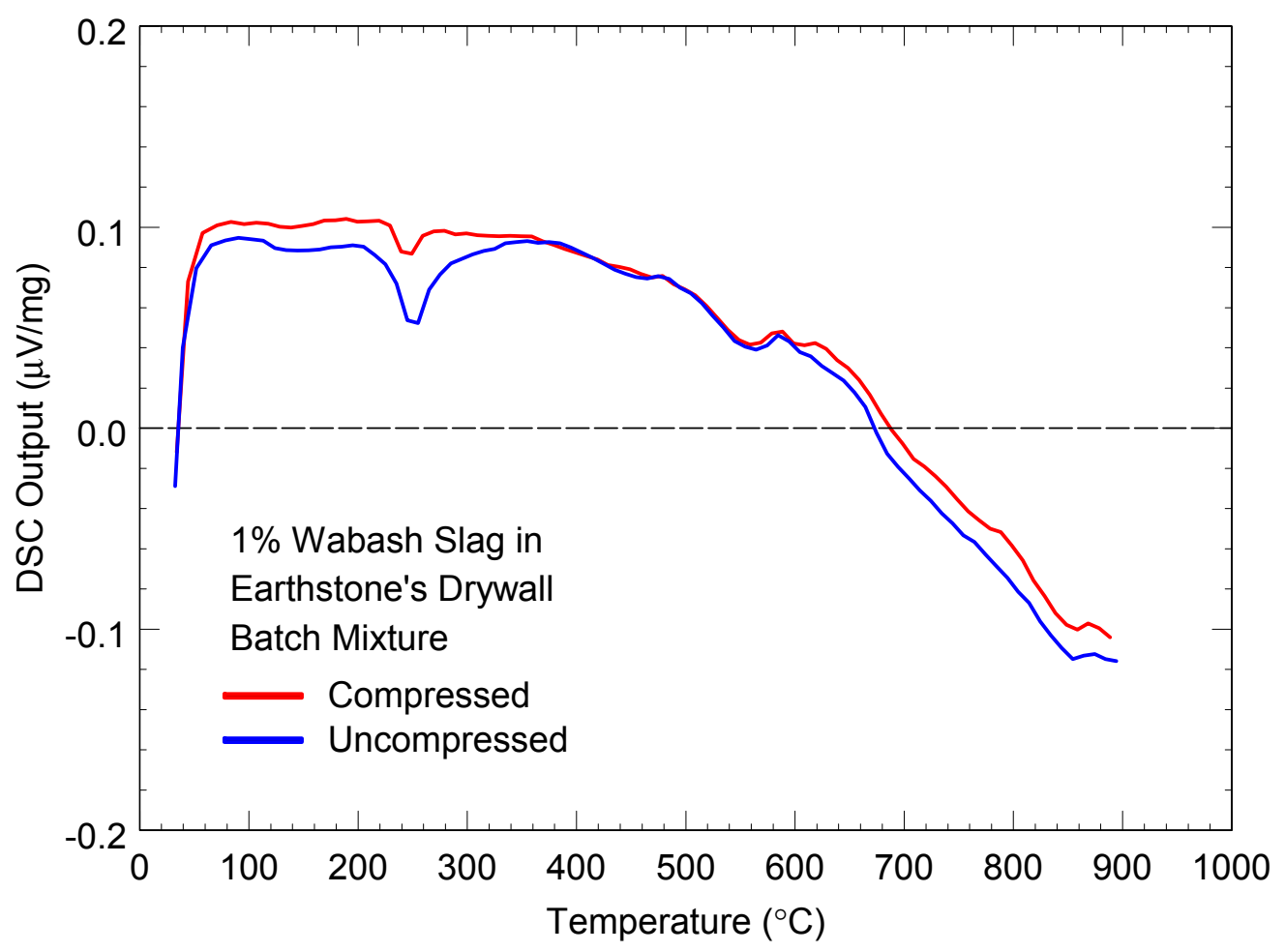

Figure 2. DSC results from a sample consisting of Earthstone's drywall batch mixture mixed with 1 per cent Wabash slag. The two curves shown differ in the preparation of the sample. In one case, the sample was a loose powder, whereas in the second case, the powder was manually tamped. No significant differences are seen.

(Explanation of "drywall batch": "Batch" refers to the powdered mixture which is placed into the furnace for foaming, consisting of ground glass, foaming agent, and colorants and other additives. "Drywall" refers to an Earthstone foamed glass product is sold as an abrasive for finishing drywall. Hence "drywall batch" is the batch mixture that Earthstone uses to produce this product.) 


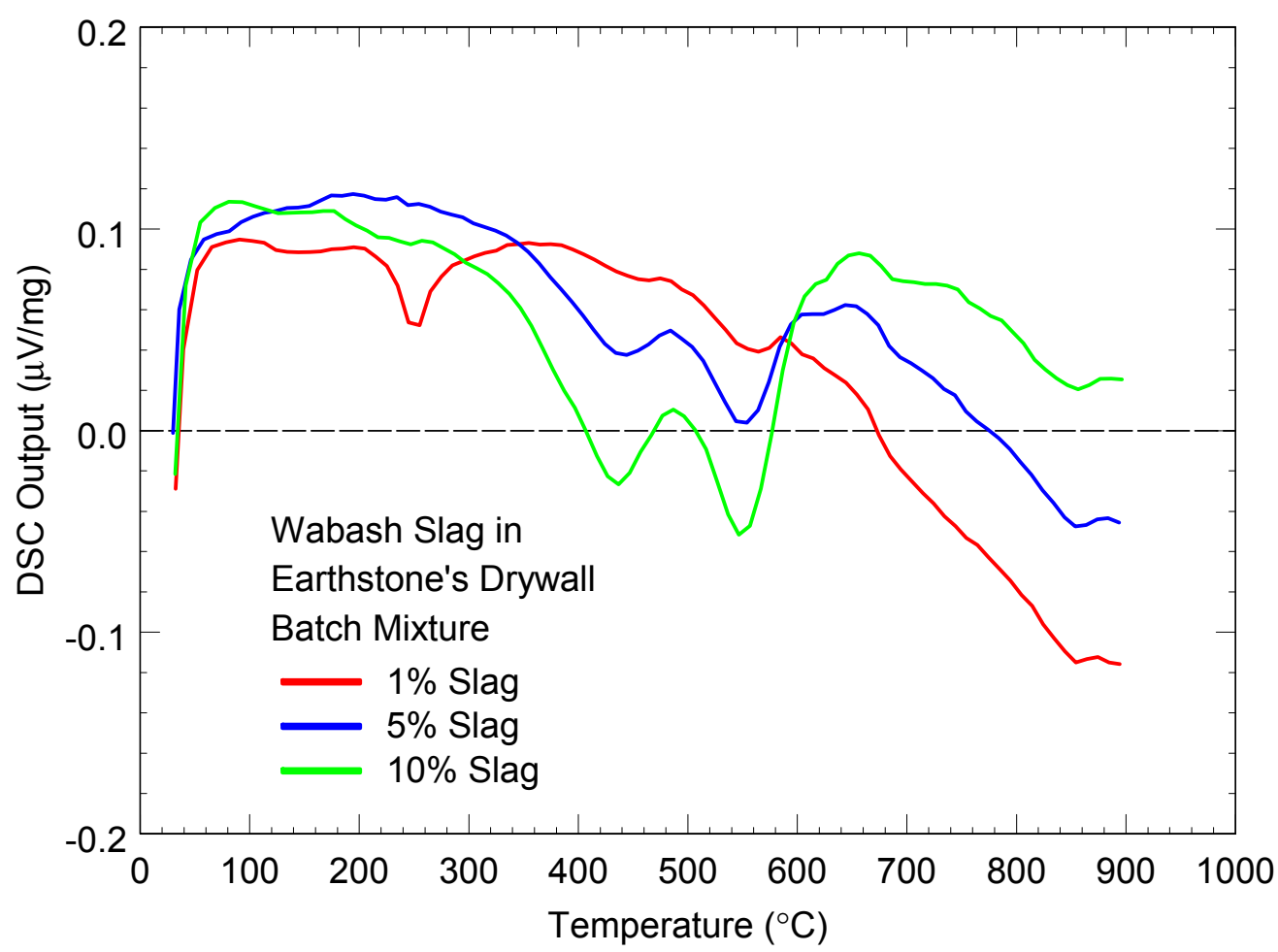

Figure 3. Samples consist of Earthstone's drywall batch mixture with different amounts of Wabash slag added. The three curves shown correspond to 1 per cent, 5 per cent, and 10 per cent slag.

The slag appears to produce an exothermic reaction, or perhaps two reactions, with peaks at $440{ }^{\circ} \mathrm{C}$ and $550{ }^{\circ} \mathrm{C}$. The reaction(s) intensify as the concentration of slag is increased. 


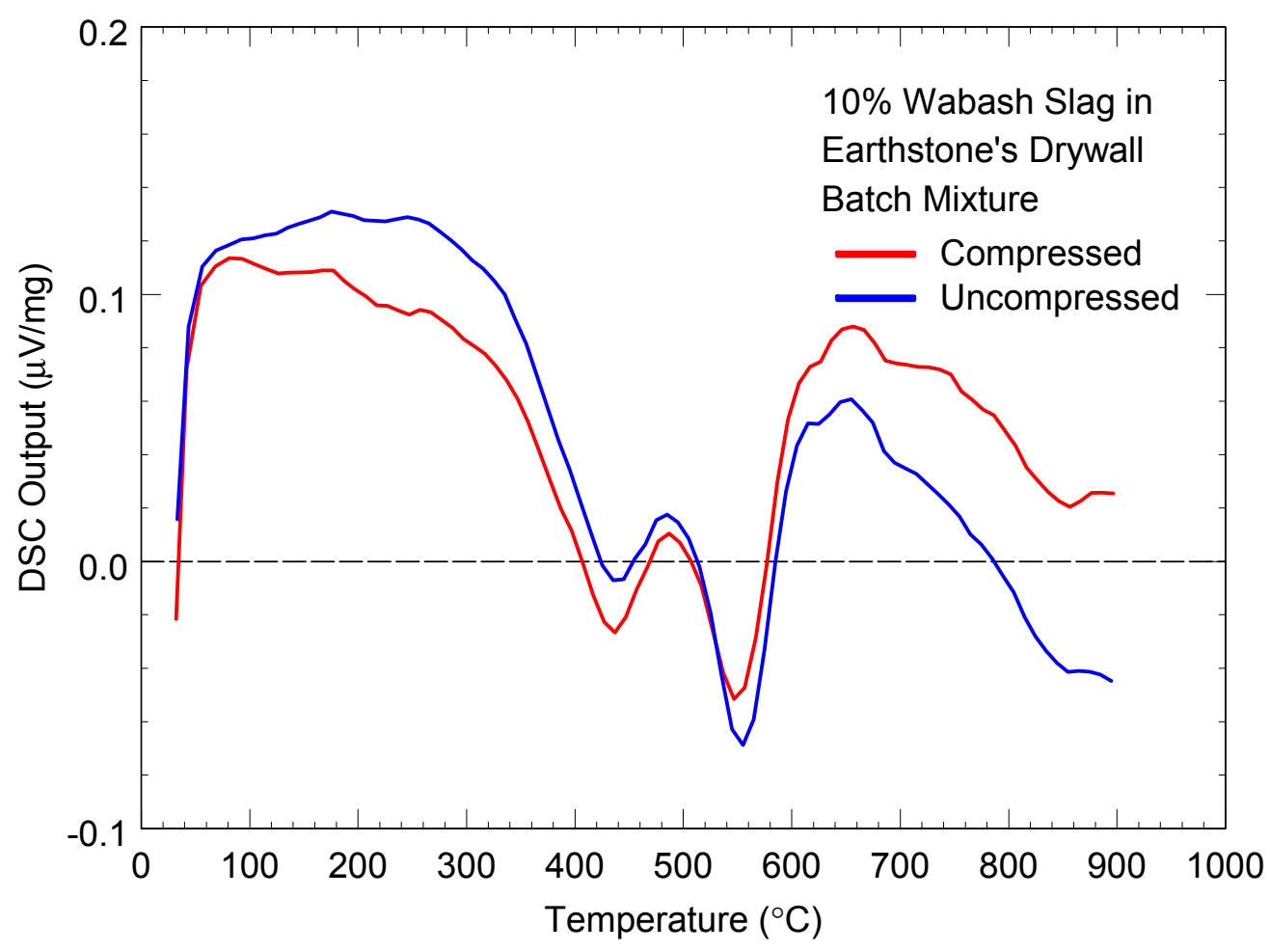

Figure 4. Here, the drywall batch mixture with 10 per cent added Wabash slag is tested as uncompressed and compressed forms. The exothermic reaction(s) seen in the previous figure are still present, and little difference is seen between the two cases. 


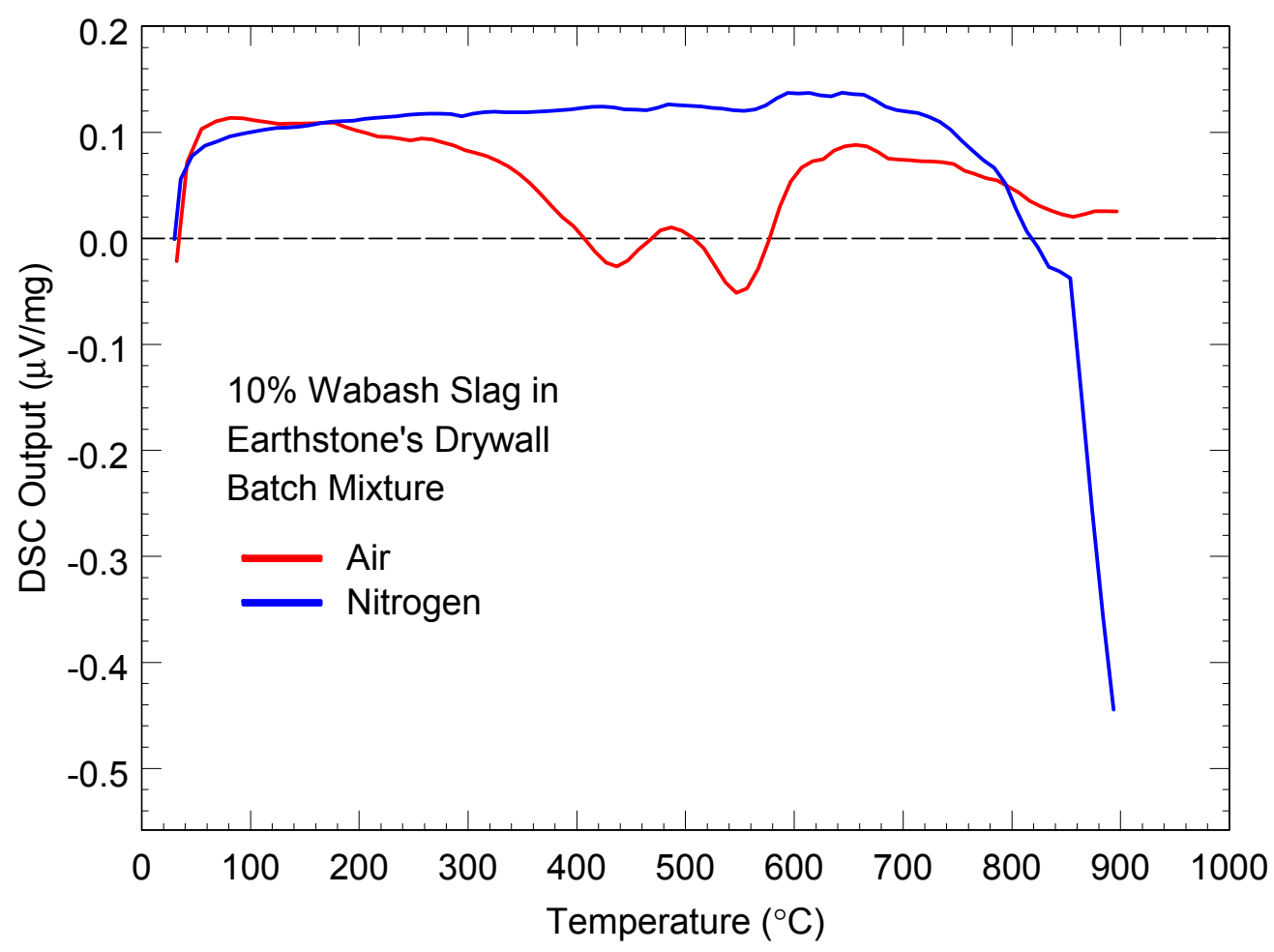

Figure 5. The same mixture, drywall batch with 10 per cent added Wabash slag, is tested in both air and nitrogen atmospheres. The exothermic reaction(s) seen previously do not appear in nitrogen, suggesting that the reaction(s) is due to oxygen. We speculate that the reaction could be combustion of unburned carbon in the slag.

The DSC data shown in previous figures were all taken with an air atmosphere surrounding the sample. 


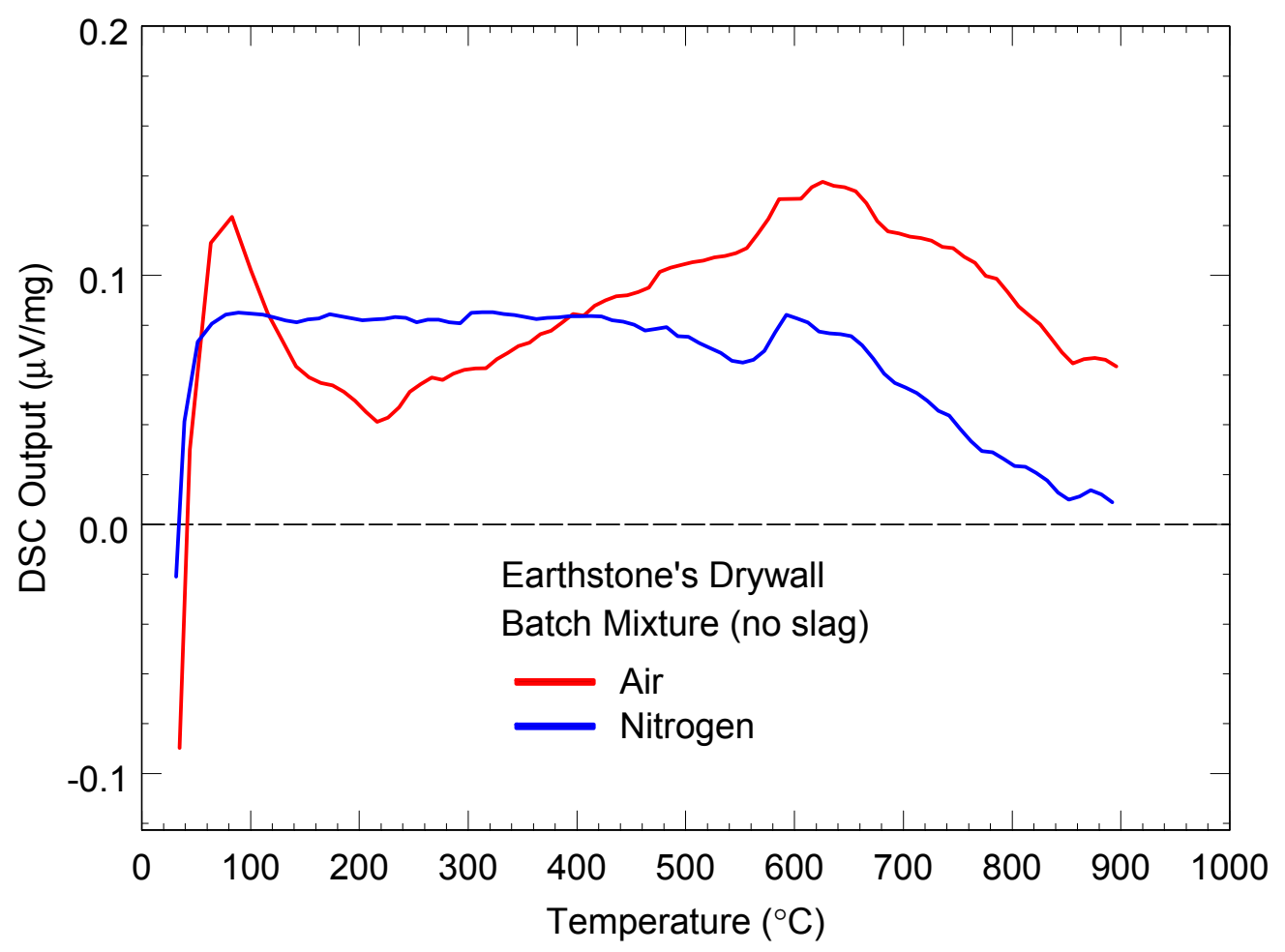

Figure 6. Here Earthstone's drywall batch mixture, with no added slag, is tested in air and nitrogen atmospheres. 


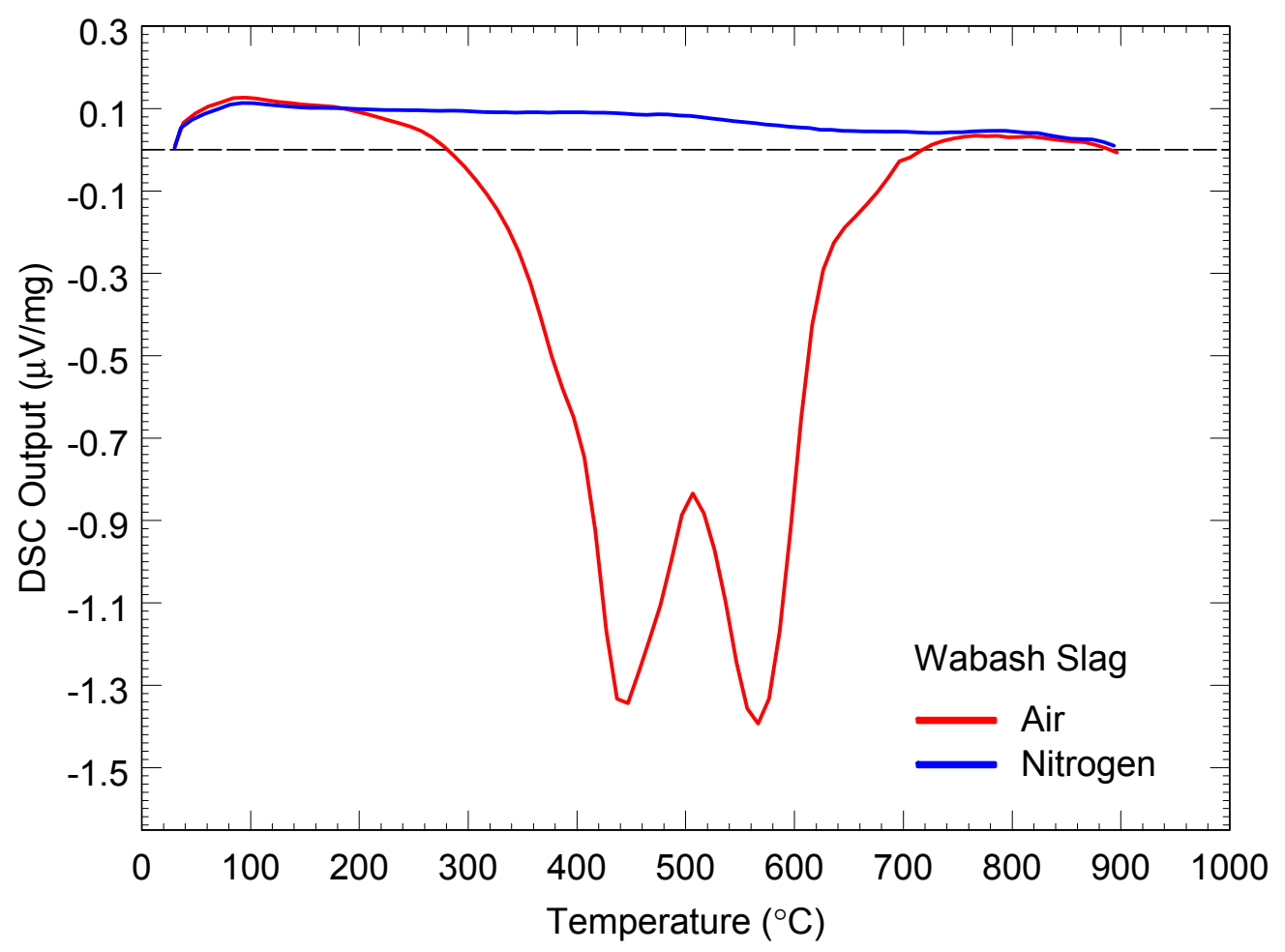

Figure 7. Samples of 100 per cent Wabash slag, with no batch mixture, are tested in air and nitrogen. The same exothermic reaction(s) seen previously is seen again in air, but not in nitrogen. 
The foaming agent in Earthstone's drywall batch is calcium carbonate, which is well matched to the soda-lime glass frit in the batch. We do not believe that the slag loadings here are sufficiently large to significantly change the melting properties of the soda-lime glass. Moreover, microscopic examination suggests that individual slag particles are still discernable in the final foamed glass, indicating that the slag does not diffuse into and mix with the glass. Differential Thermal Analysis (DTA) scans of the foamed glass containing slag likewise do not indicate any significant changes in the softening point.

Due to the relatively low concentration of slag that could be successfully foamed, the thermal visco-elastic properties were dominated by the soda-lime glass. As limestone is the most economic and efficient foaming agent for the soda-lime glass, no other foaming agents were viable for testing.

Instead of using different foaming agents, batches of glass foam were made with varying amounts of calcium carbonate foaming agent, and the addition of surface agents, abrasive agents, and stains. Experiments were also conducted in which the particle size of the ground glass frit was varied. 


\section{Phase 2. Evaluation of Material Properties of Slag Foams}

Task 1. Evaluate shear strength, tensile strength, and modulus of rupture.

Approach: Only foamed glass made with Wabash slag was tested in this task. The results of phase 1 indicated that that the Wabash slag showed much more promise as a foamed glass additive.

4-Point bend testing: Using an Instron Model 5869 table top testing machine, several compositions of the slag-reinforced Earthstone dry wall composition were measured for strength in a 4-point bend testing mode. Figure 8 shows the testing machine. (The test apparatus was set up according to ASTM C 1161-90 for advanced ceramics.) In our first tests, some specimens seemed to crack near one of the four supports of the test fixture, instead of cracking in the middle where the bending stress is greatest. To reduce this problem, single layers of household aluminum foil were placed between the test fixture supports and the foamed glass specimens in order to spread out the concentrated load at the supports. Figure 9 shows a foamed glass test specimen in the 4-point bend test fixture. Figure 10 shows a test specimen after it has failed.

The materials tested include the basic Earthstone dry wall composition and that same composition with the following alterations:

$1 \%$ Slag, 200 series glass, $1 \% \mathrm{CaCO}_{3}$

$1 \%$ Slag, 300 series glass, $1 \% \mathrm{CaCO}_{3}$

$3 \%$ Slag, 200 series glass, $1 \% \mathrm{CaCO}_{3}$

$3 \%$ Slag, 300 series glass, $1 \% \mathrm{CaCO}_{3}$

$7 \%$ Slag, 300 series glass, $1 \% \mathrm{CaCO}_{3}$

The slag and calcium carbonate were added to the Earthstone batch mixture in the indicated amounts. (The calcium carbonate foaming agent is in addition to the calcium carbonate already present in the batch mixture.) The annotations "200 series glass" and "300 series glass" refer to the ground glass frit, which is the major constituent of the batch mixture. Note that the designations 200 and 300 do not refer to screen sizes. Earthstone uses the designation 200 series for a ground glass frit with a median particle diameter between 9 and 11 microns, and 300 series for a median particle diameter between 7 and 9 microns. The baseline Earthstone drywall product is made with 300 series glass.

Constant cross head movement was applied to test the specimens at a rate of 0.508 $\mathrm{mm} /$ minute $(0.02 \mathrm{in} / \mathrm{min})$ until the specimen failed. Data was plotted as compressive extension versus compressive load. Figure 11 shows a typical data record.

Compressive strength: Using the same Instron Model 5869 table top testing machine, we tested several cubes of Earthstone drywall composition and one with $5 \%$ slag, $0.5 \% \mathrm{ZnO}$, 
and $0.85 \% \mathrm{CaCO}_{3}$. The cubes were simply placed between the platens of the base and the load cell.

Shear strength: Shear strength tests are generally run on ceramic coatings, not on bulk ceramic or brittle materials. The performance of the foam glass in 4-point bend testing provides a better indication of the overall performance of the material. Thus, we did not perform any shear strength testing.

\section{$\underline{\text { Results: }}$}

4-point bend testing: Table 1 summarizes the failure for all the specimens. Photographs of some of the specimens are provided in Figures 12 through 16.

Some comments on the materials' behavior:

Raw Earthstone drywall: The strength of $1780 \mathrm{kPa}(258 \mathrm{psi})$ is a good baseline from which to judge the other materials. The relative standard deviation of $2 \%$ is a testament to the consistency of the manufacturing process. The other materials, because they have only been produced this one time, would not be expected to show such behavior.

$1 \%$ slag, 200 series glass, $1 \% \mathrm{CaCO}_{3}$ : The strength of $1720 \mathrm{kPa}(249 \mathrm{psi})$ is nearly the same as that of the base material. The relative standard deviation of $17 \%$ is more typical of brittle materials.

$1 \%$ slag, 300 series glass, $1 \% \mathrm{CaCO}_{3}$ : The strength of $1590 \mathrm{kPa}(230 \mathrm{psi})$ is less than that of the $1 \%$ composition made with 200 series glass. The smaller particle size appears to create larger pores, and thus a weaker material. The relative standard deviation of $9 \%$ indicates a fairly consistent flaw or pore size from sample to sample.

$3 \%$ slag, 200 series glass, $1 \% \mathrm{CaCO}_{3}$ : The strength of $1910 \mathrm{kPa}(277 \mathrm{psi})$ is perhaps a little better than that of the base material. The relative standard deviation of $21 \%$ is more typical of brittle materials.

$3 \%$ slag, 300 series glass, $1 \% \mathrm{CaCO}_{3}$ : The strength of $1370 \mathrm{kPa}(198 \mathrm{psi}$ ) shows a major decrease compared both with the base material and the 3\% composition made with 200 series glass. As mentioned above, the smaller particle size appears to create larger pores, and thus, in this case, a much weaker material. The relative standard deviation of $9 \%$ indicates a fairly consistent flaw or pore size from sample to sample, and is coincidentally similar to the relative standard deviation of the $1 \%$ composition made with 300 series glass.

$7 \%$ slag, 300 series glass, $1 \% \mathrm{CaCO}_{3}$ : The strength of $2520 \mathrm{kPa}(365 \mathrm{psi})$ is a significant improvement over the base material. The relative standard deviation of $9 \%$ again indicates a fairly consistent flaw or pore size from sample to sample. The strength and consistency of this material hold great promise as an improved foam glass product requiring better mechanical properties. 
Compressive strength: Starting at a crosshead speed of $0.508 \mathrm{~mm} / \mathrm{minute}(0.02 \mathrm{in} / \mathrm{min})$, we crushed the first sample of the drywall composition and found that it did not break, but simply crushed. Similar results were obtained at $5.08 \mathrm{~mm} / \mathrm{min}(0.2 \mathrm{in} / \mathrm{min})$ and 50.8 $\mathrm{mm} / \mathrm{min}(2.0 \mathrm{in} / \mathrm{min})$ crosshead speeds. At the fastest rate, the cube was crushed nearly to half its height before we stopped the test. The $50.8 \mathrm{~mm}$ ( 2 inch) cube was sustaining a load of greater than 1780 Newtons (400 pounds), which corresponds to a compressive stress of more than $690 \mathrm{kPa}(100 \mathrm{psi})$.

Testing the composition with $5 \%$ slag, $0.5 \% \mathrm{ZnO}$, and $0.85 \% \mathrm{CaCO}_{3}$ at $50.8 \mathrm{~mm} / \mathrm{min}$ ( $2.0 \mathrm{in} / \mathrm{min})$, the material crushed for about half a centimeter (1/4 inch) and then failed abruptly as though four cracks rapidly coalesced and nearly pulverized the sample. This $50.8 \mathrm{~mm}$ ( 2 inch) cube failed at a load of 5740 Newtons (1290 pounds), which corresponds to a compressive stress of $2220 \mathrm{kPa}(322.5 \mathrm{psi})$. Figure 17 is a photo of this and one of the drywall samples. 


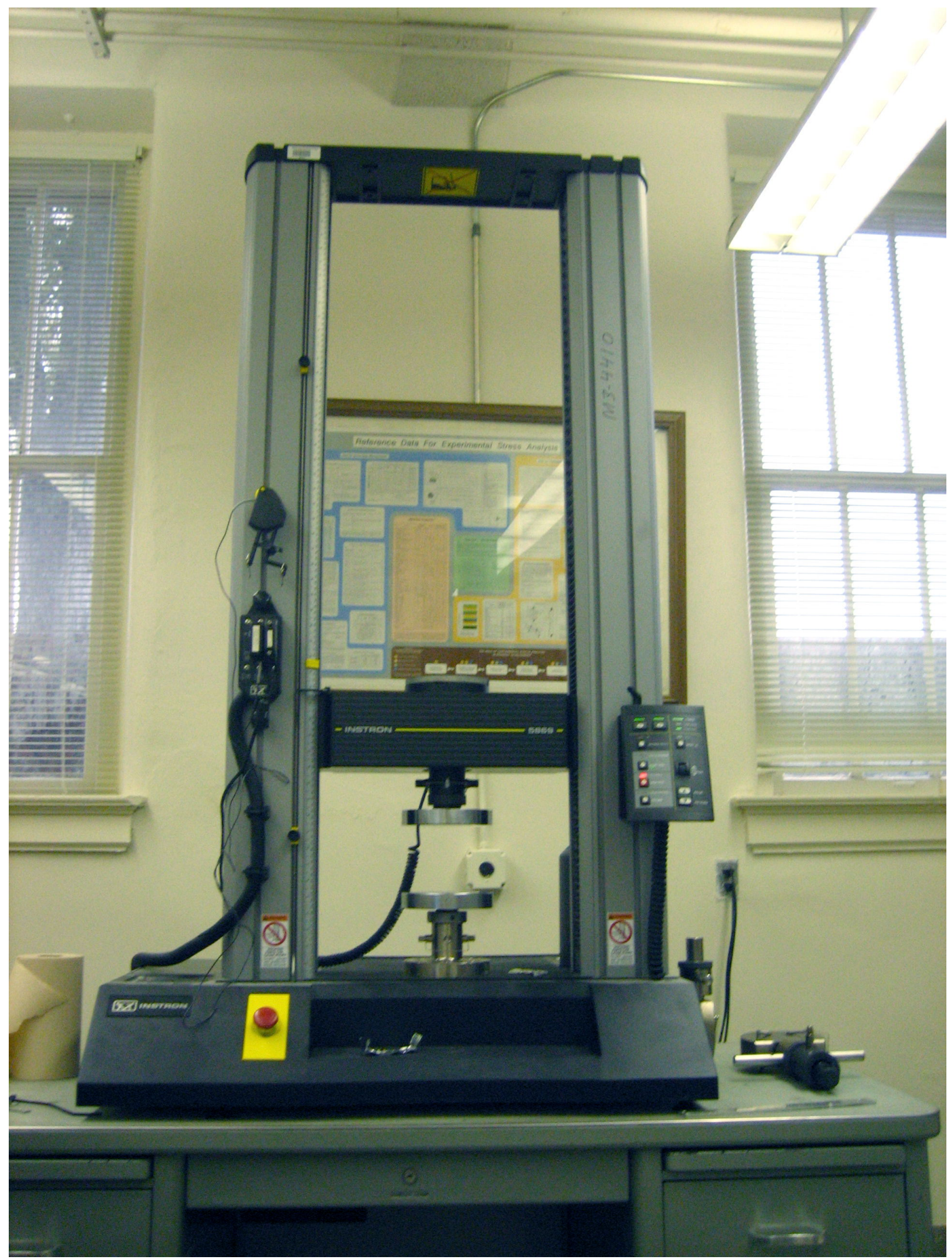

Figure 8. The Instron testing machine used for mechanical strength measurements. 


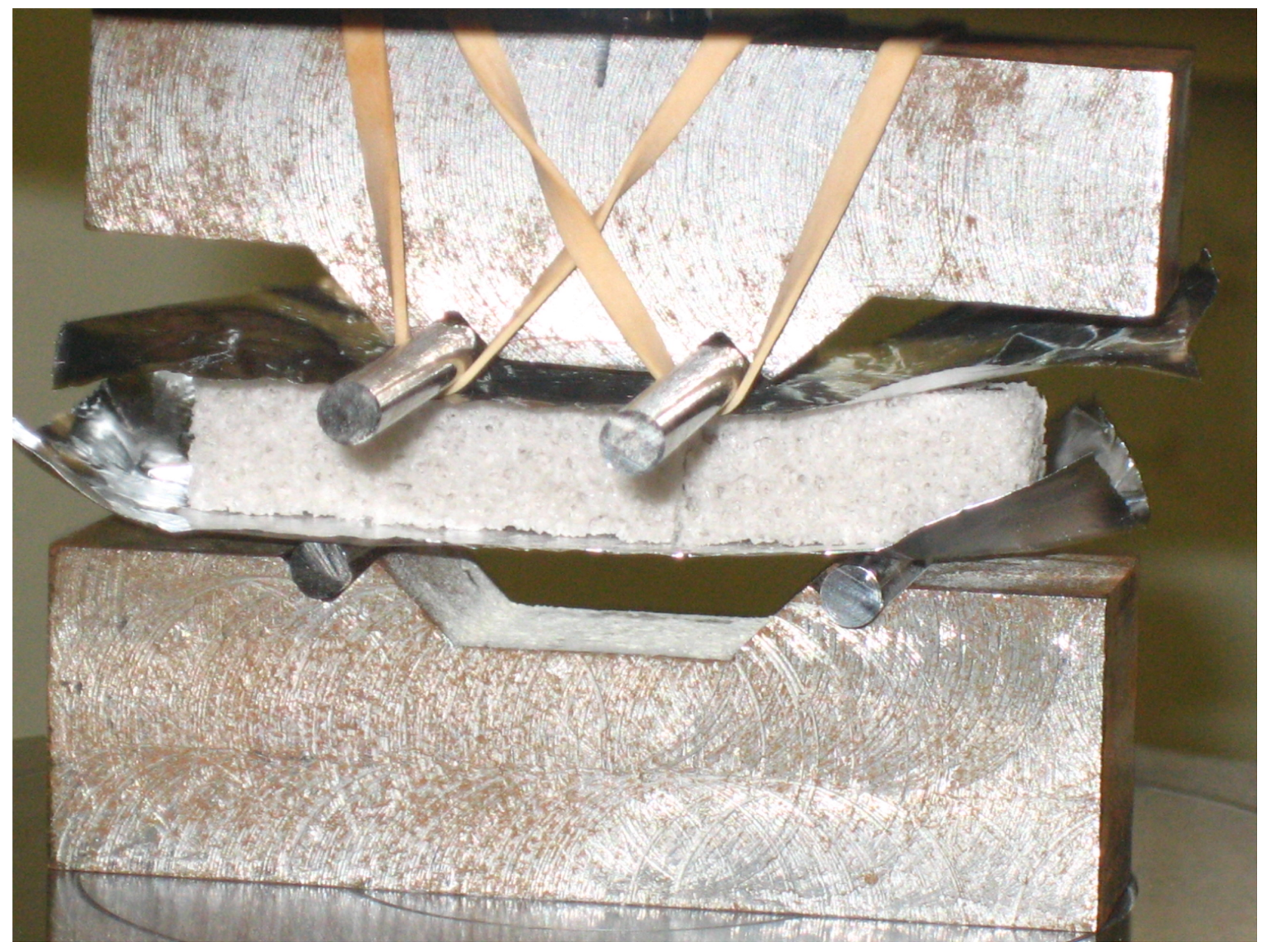

Figure 9. A foamed glass test specimen mounted in the four-point bending test fixture.

\begin{tabular}{|c|c|l|l|}
\hline \multicolumn{4}{|c|}{ Table 1. Results of four-point bending tests. } \\
\hline Composition & $\begin{array}{c}\text { Failure } \\
\text { stress kPa } \\
\text { (psi) }\end{array}$ & $\begin{array}{c}\text { Standard } \\
\text { deviation } \mathrm{kPa} \\
\text { (psi) }\end{array}$ & $\begin{array}{c}\text { Relative } \\
\text { standard } \\
\text { deviation (\%) }\end{array}$ \\
\hline Raw Earthstone Drywall & $1780(258)$ & $28(4)$ & 2 \\
\hline 1\% Slag, 200 series glass, 1\% CaCO 3 & $1720(249)$ & $290(42)$ & 17 \\
\hline 1\% Slag, 300 series glass, 1\% $\mathrm{CaCO}_{3}$ & $1590(230)$ & $150(22)$ & 9 \\
\hline 3\% Slag, 200 series glass, 1\% $\mathrm{CaCO}_{3}$ & $1910(277)$ & $390(57)$ & 21 \\
\hline 3\% Slag, 300 series glass, 1\% $\mathrm{CaCO}_{3}$ & $1370(198)$ & $120(18)$ & 9 \\
\hline 7\% Slag, 300 series glass, 1\% $\mathrm{CaCO}_{3}$ & $2520(365)$ & $230(33)$ & 9 \\
\hline
\end{tabular}




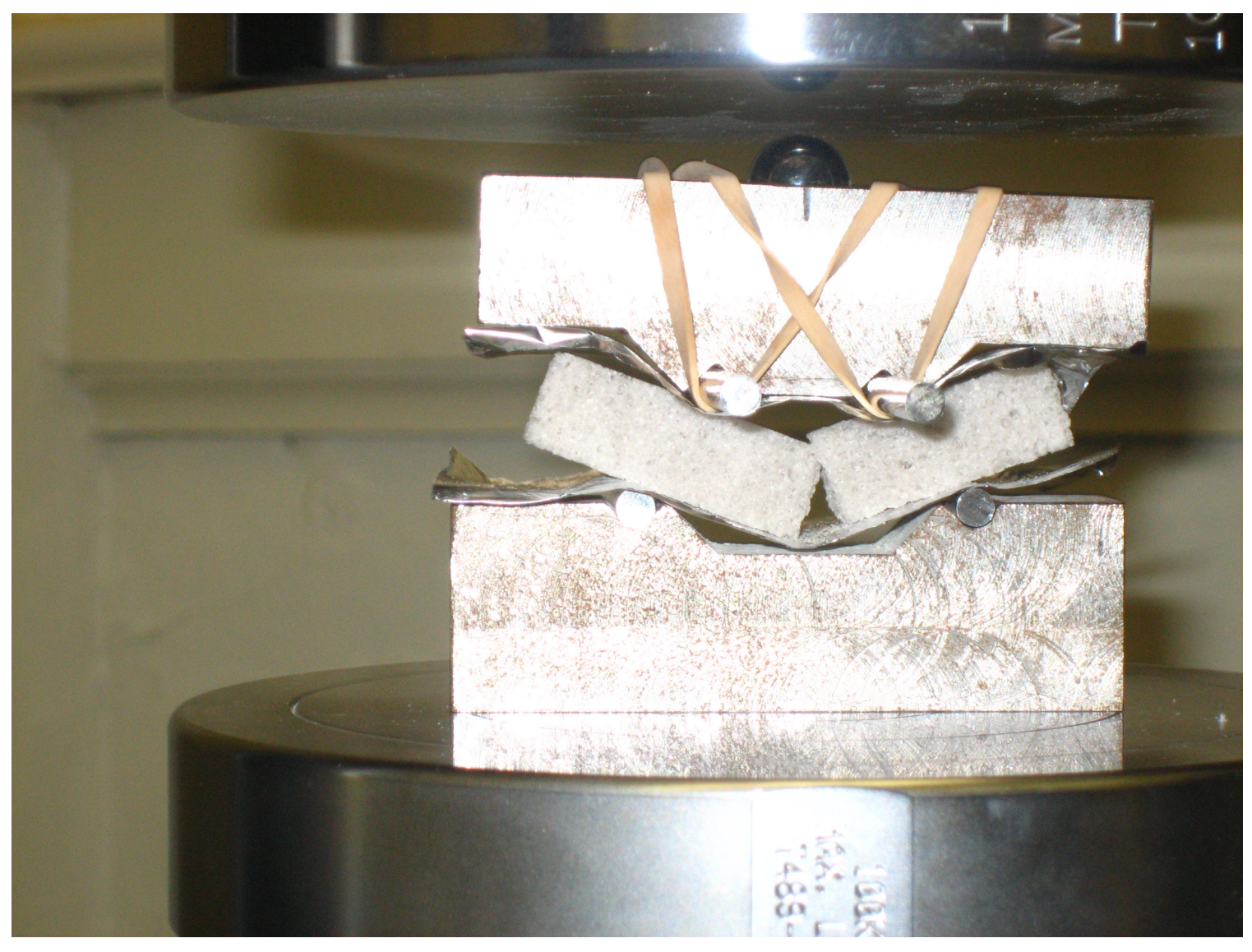

Figure 10. A four-point bending specimen after breaking. 


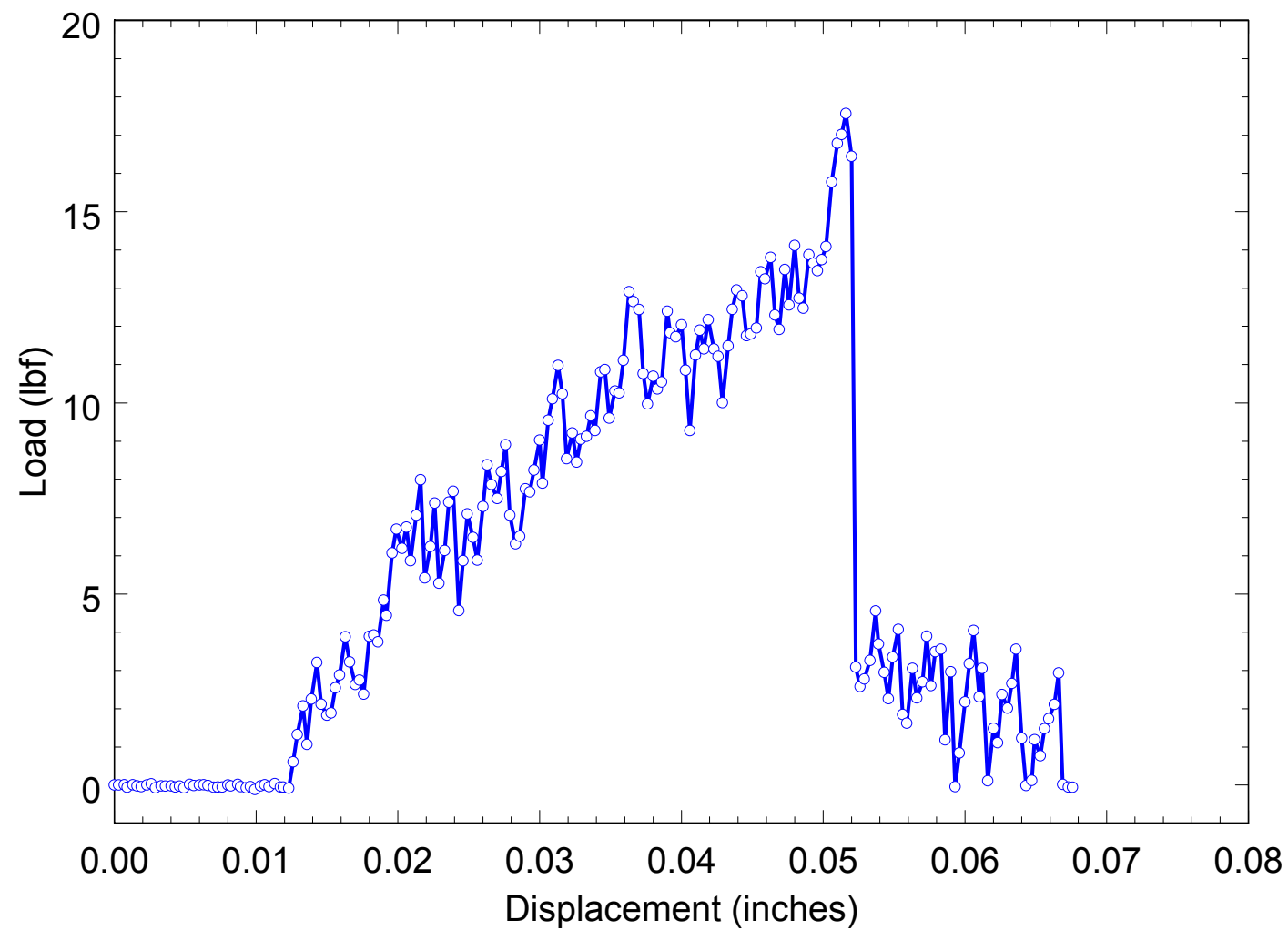

Figure 11. Sample output from Instron testing machine. Here, a sample of Earthstone drywall product, with no added slag, was tested in four point bending. In this test, the specimen failed when the applied load reached 78.3 Newtons (17.6 pounds). The specimen in this test was the baseline Earthstone drywall product, with no slag added. 


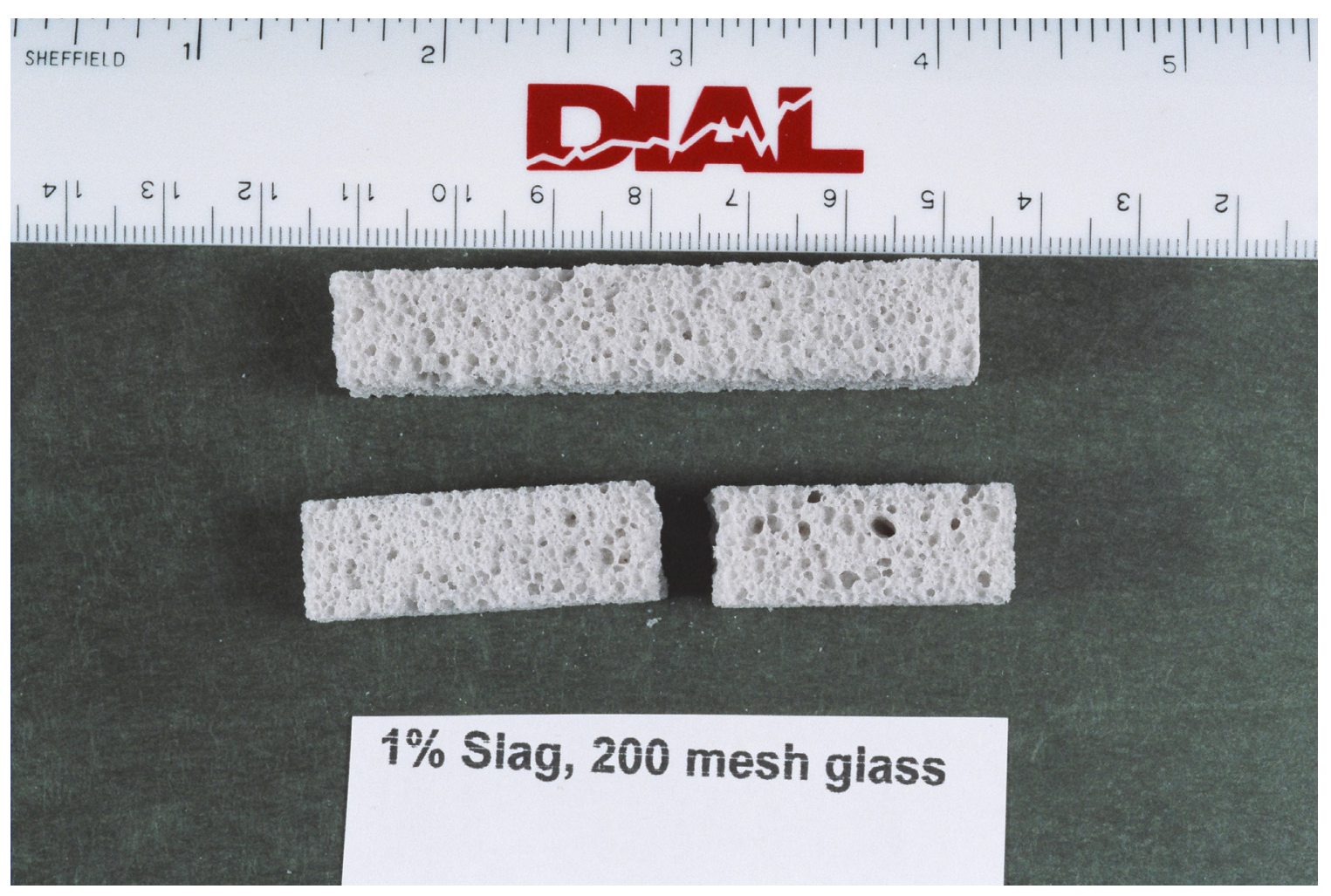

Figure 12. An unbroken test specimen for the four point bending test and a broken specimen. These specimens contained 1\% Wabash slag, and was made using 200 series glass, with a median particle diameter between 9 and 11 microns. 


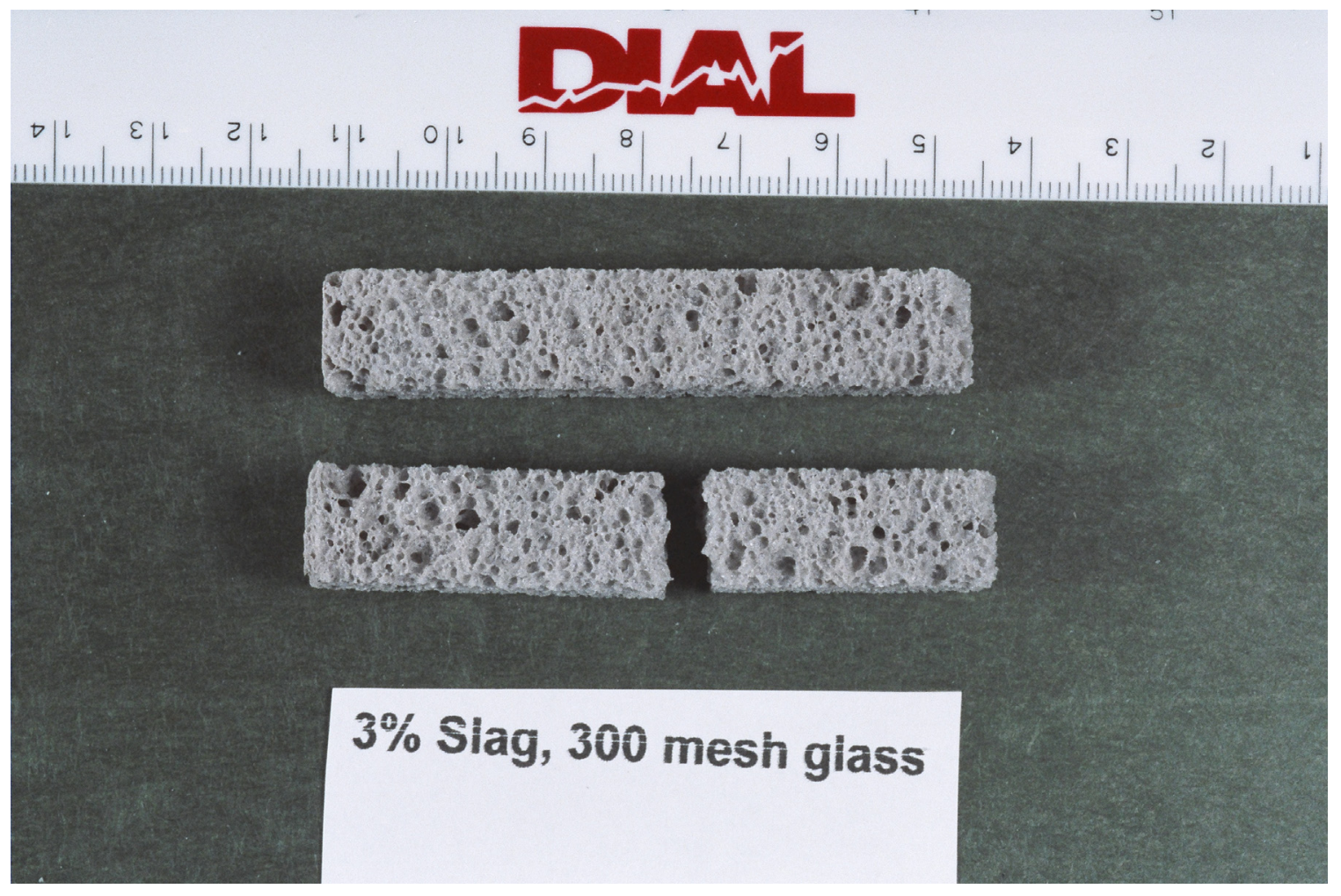

Figure 13. An unbroken test specimen for the four point bending test and a broken specimen. These specimens contained 3\% Wabash slag, and 300 series glass frit was used. (300 series glass has a median particle diameter between 7 and 9 microns.) The scale at the top of the picture is graduated in centimeters and millimeters. 


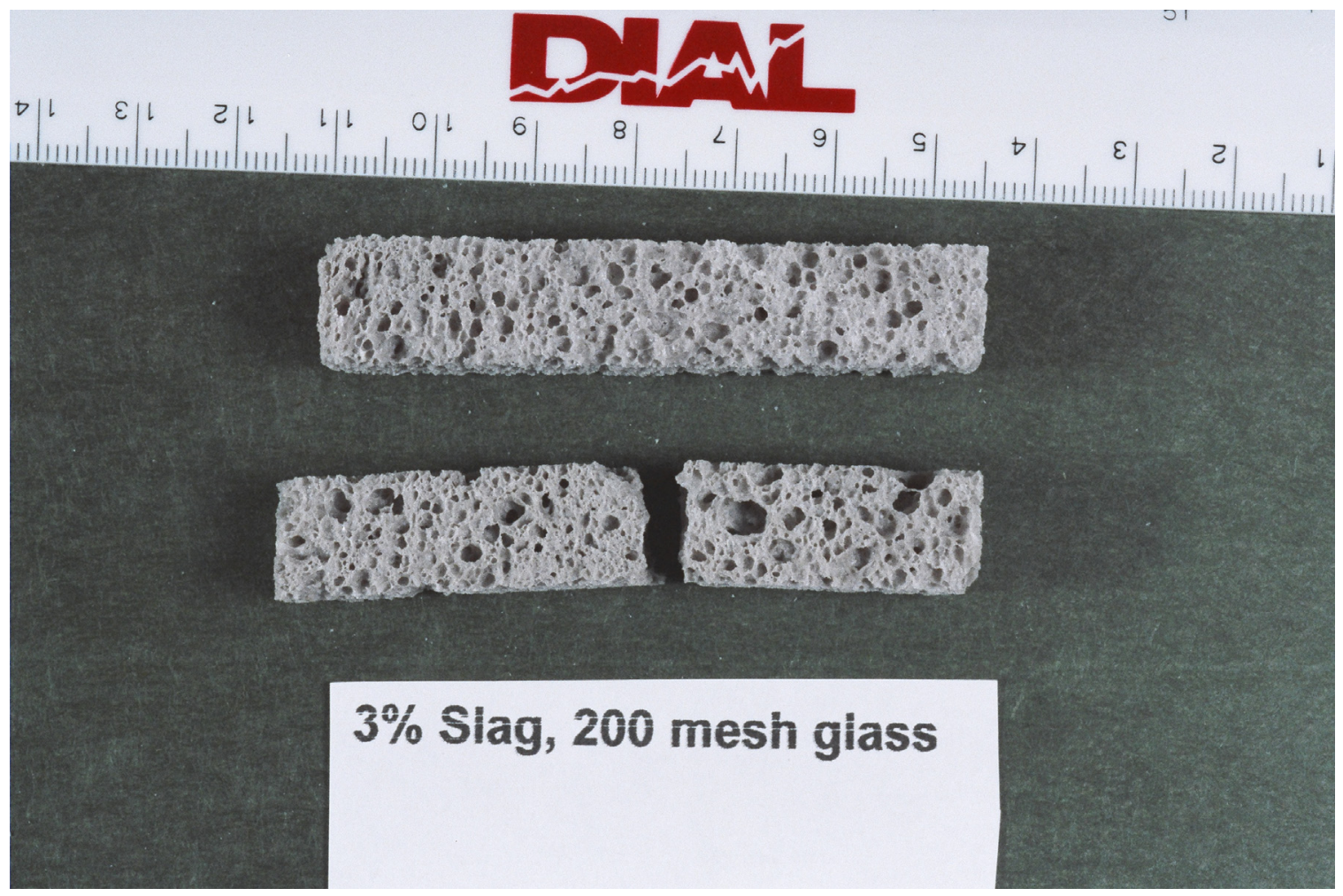

Figure 14. An unbroken test specimen for the four point bending test and a broken specimen. These specimens contained 3\% Wabash slag, and the glass frit used was screened through a 200 series screen. 


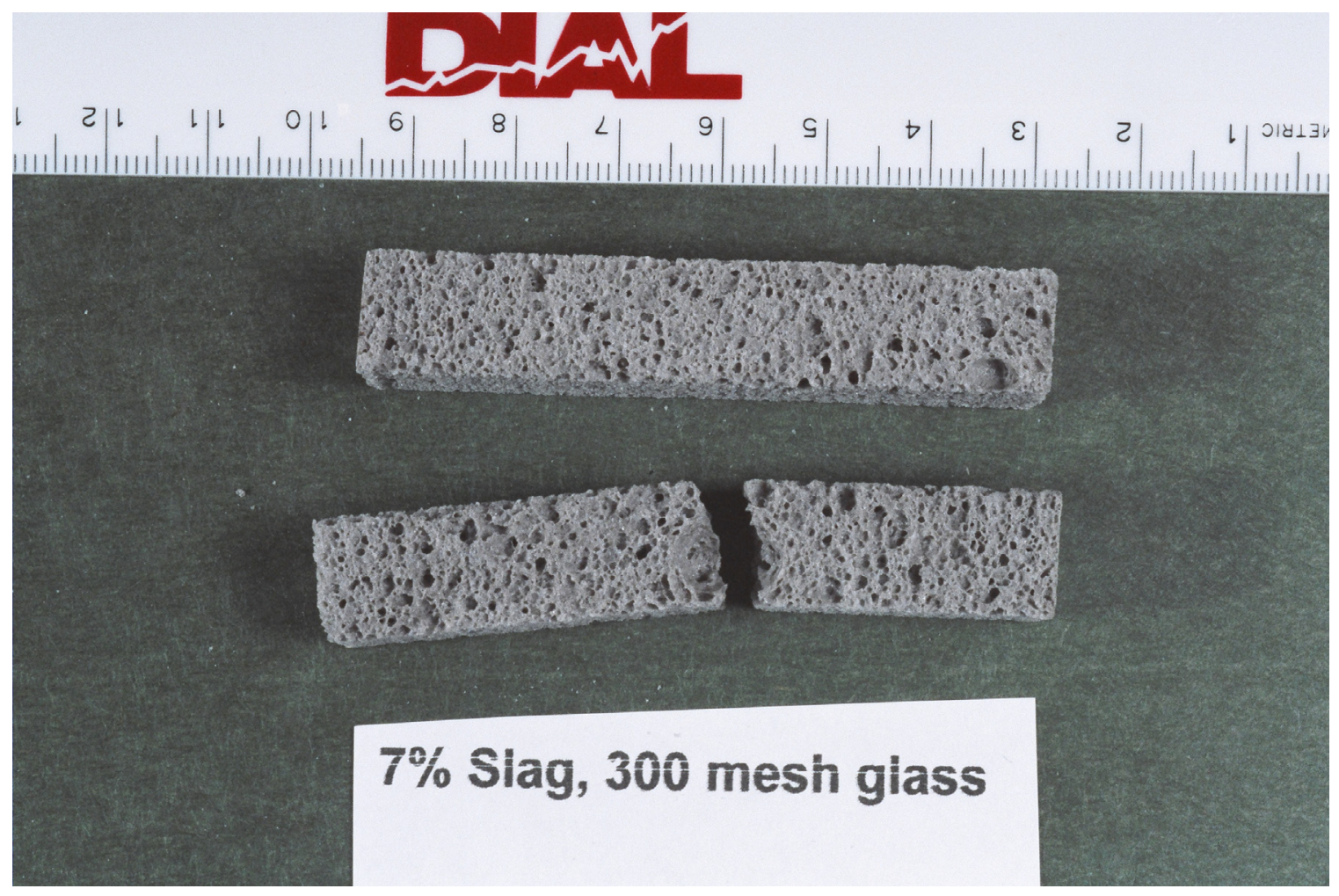

Figure 15. An unbroken test specimen for the four point bending test and a broken specimen. These specimens contained 7\% Wabash slag, and the glass frit used was 300 series. 


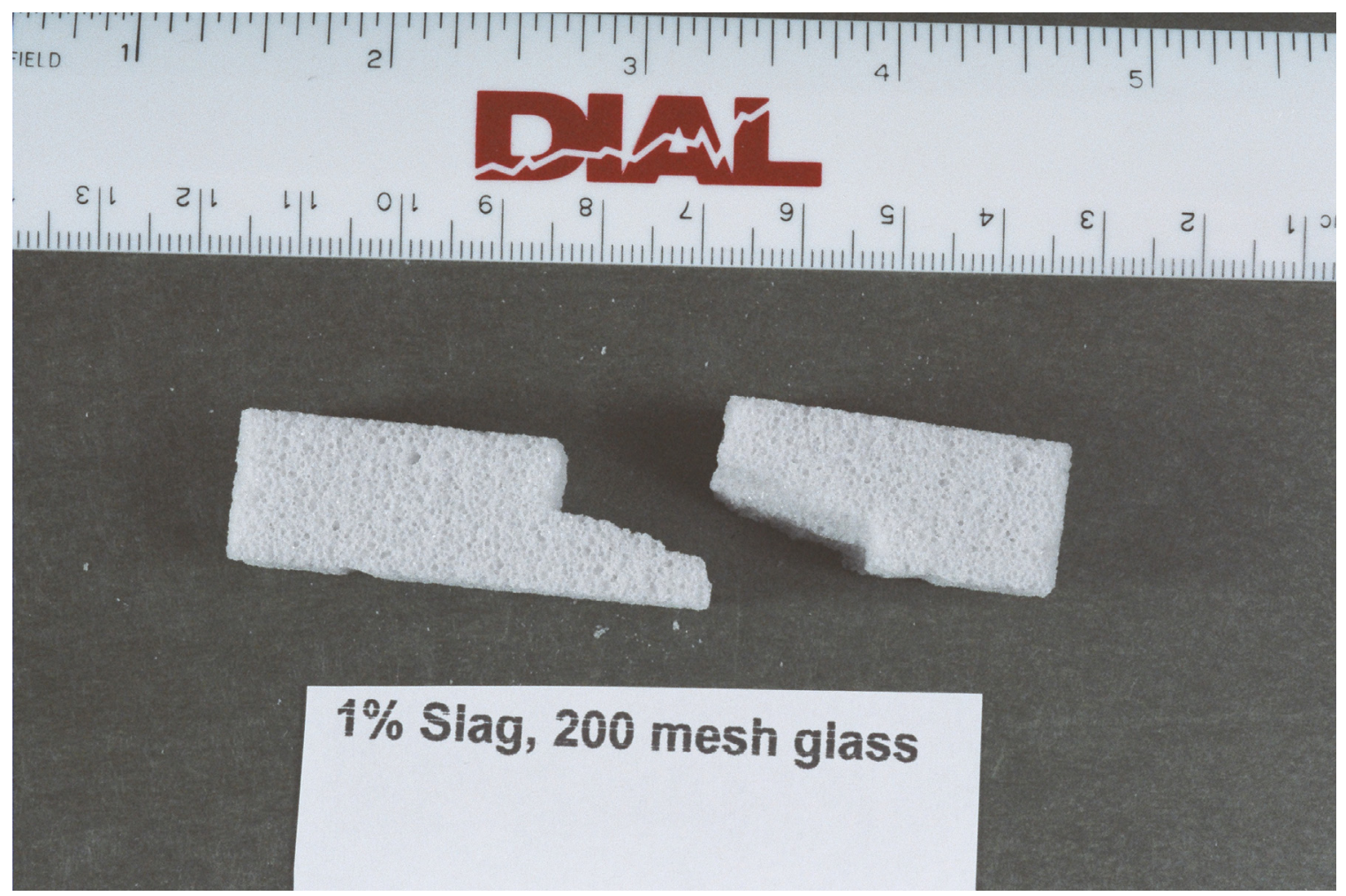

Figure 16. A broken specimen from the four point bending tests. This specimen exhibits an irregular fracture pattern that was observed on occasion. 


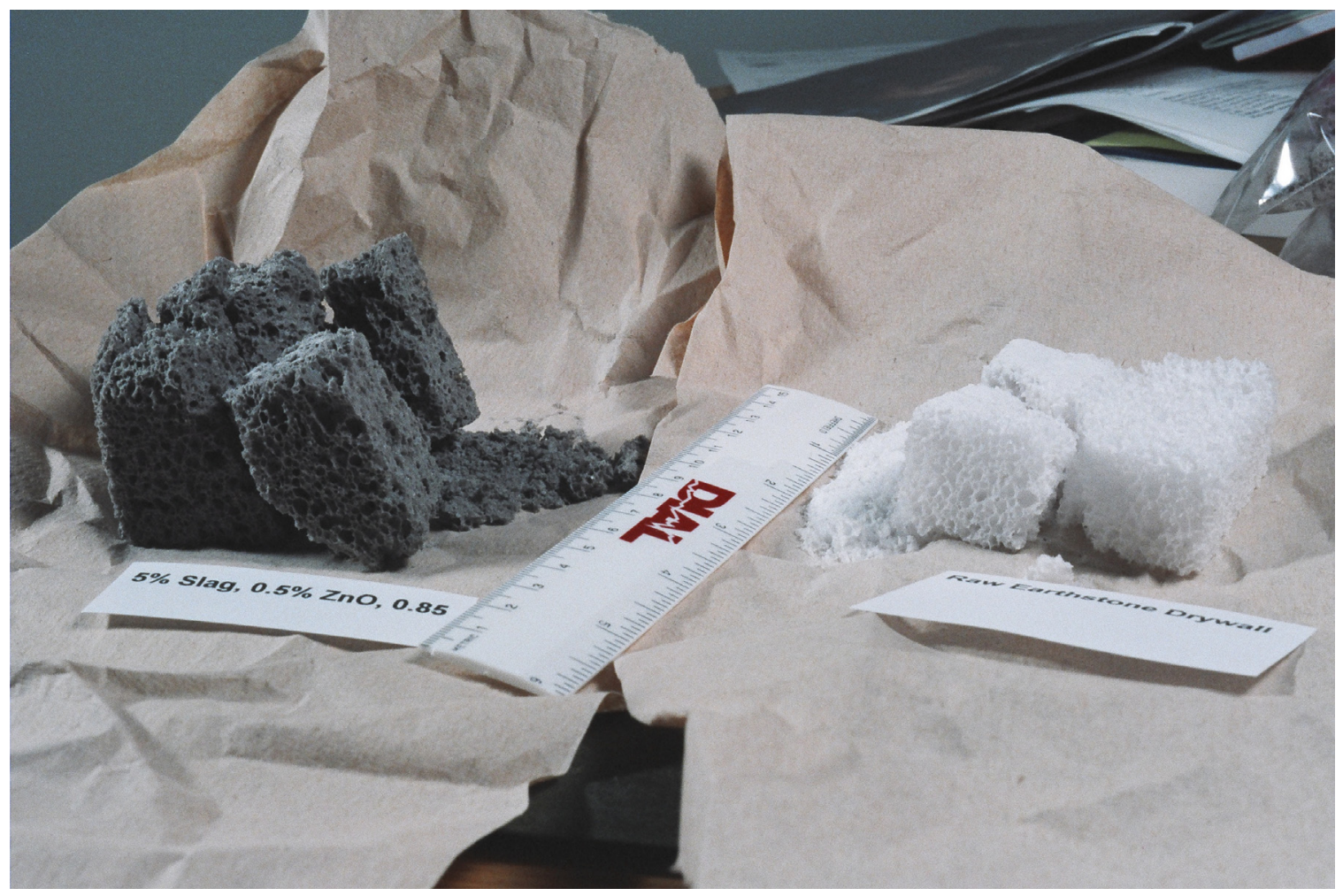

Figure 17. Fractured samples from compressive(crushing) strength tests. On the left is the foamed glass sample with $5.0 \%$ Wabash slag, $0.5 \%$ zinc oxide, and $0.85 \%$ calcium carbonate. On the right is the sample of the baseline drywall product. These test specimens were originally $50.8 \times 50.8 \times 50.8 \mathrm{~mm}(2 \times 2 \times 2$ inch $)$ cubes. 
Task 2. Determine ratio of closed cell to open cell material in the foam slag.

\section{Approach.}

The bulk density of the foam is an excellent measure of its porosity. Porosity is defined as the fraction of the total volume which is constituted by bubbles, voids, and the like. To a good approximation, changes in the foam bulk density are indicative of changes in porosity. Bulk density is an easy measurement. A rectangular parallelepiped is cut from a large piece of foamed glass, its dimensions are measured and volume computed, and the sample is then weighed. The bulk density is the volume divided by the mass.

Cell (bubble) size and interconnectivity can be qualitatively studied by examining samples with a microscope. We have also taken some extreme close-up (macro) photographs of the foamed glass.

$\underline{\text { Results. }}$

Table 2 gives the results of density measurement made by Earthstone. Table 3 gives the results of similar measurement made at DIAL/MSU.

\begin{tabular}{|l|ll|}
\hline \multicolumn{3}{|c|}{ Table 2. Foam glass density (Earthstone measurements) } \\
\hline Composition & \multicolumn{2}{|c|}{ Foam glass density, grams $/ \mathrm{cm}^{3}\left(\mathrm{lb}_{\mathrm{m}} / \mathrm{ft}^{3}\right)$} \\
\hline $0.3 \%$ slag, $0.5 \% \mathrm{ZnO}, 0.85 \% \mathrm{CaCO}_{3}$ & 0.18 & $(11.2)$ \\
\hline $1.0 \%$ slag, $0.5 \% \mathrm{ZnO}, 0.85 \% \mathrm{CaCO}_{3}$ & 0.19 & $(11.9)$ \\
\hline $3.0 \%$ slag, $0.5 \% \mathrm{ZnO}, 0.85 \% \mathrm{CaCO}_{3}$ & 0.20 & $(12.5)$ \\
\hline $5.0 \%$ slag, $0.5 \% \mathrm{ZnO}, 0.85 \% \mathrm{CaCO}_{3}$ & 0.33 & $(20.6)$ \\
\hline
\end{tabular}

\begin{tabular}{|l|ll|}
\hline \multicolumn{3}{|c|}{ Table 3. Foam glass density (DIAL measurements) } \\
\hline Composition & \multicolumn{2}{|c|}{ Foam glass density, grams $/ \mathrm{cm}^{3}\left(\mathrm{lb}_{\mathrm{m}} / \mathrm{ft}^{3}\right)$} \\
\hline Earthstone Drywall & 0.15 & $(9.4)$ \\
\hline 1.0\% Slag, 200 series glass, $1 \% \mathrm{CaCO}_{3}$ & 0.24 & $(15.0)$ \\
\hline $1.0 \%$ Slag, 300 series glass, $1 \% \mathrm{CaCO}_{3}$ & 0.23 & $(14.4)$ \\
\hline $3.0 \%$ Slag, 200 series glass, $1 \% \mathrm{CaCO}_{3}$ & 0.26 & $(16.2)$ \\
\hline 3.0\% Slag, 300 series glass, $1 \% \mathrm{CaCO}_{3}$ & 0.28 & $(17.5)$ \\
\hline 7.0\% Slag, 300 series glass, $1 \% \mathrm{CaCO}_{3}$ & 0.39 & $(24.4)$ \\
\hline $0.3 \%$ Slag, 0.5\% ZnO, 0.85\% $\mathrm{CaCO}_{3}$ & 0.24 & $(15.0)$ \\
\hline $1.0 \%$ Slag, 0.5\% ZnO, 0.85\% $\mathrm{CaCO}_{3}$ & 0.22 & $(13.7)$ \\
\hline $3.0 \%$ Slag, 0.5\% $\mathrm{ZnO}, 0.85 \% \mathrm{CaCO}_{3}$ & 0.23 & $(14.4)$ \\
\hline $5.0 \%$ Slag, 0.5\% $\mathrm{ZnO}, 0.85 \% \mathrm{CaCO}_{3}$ & 0.30 & $(18.7)$ \\
\hline
\end{tabular}




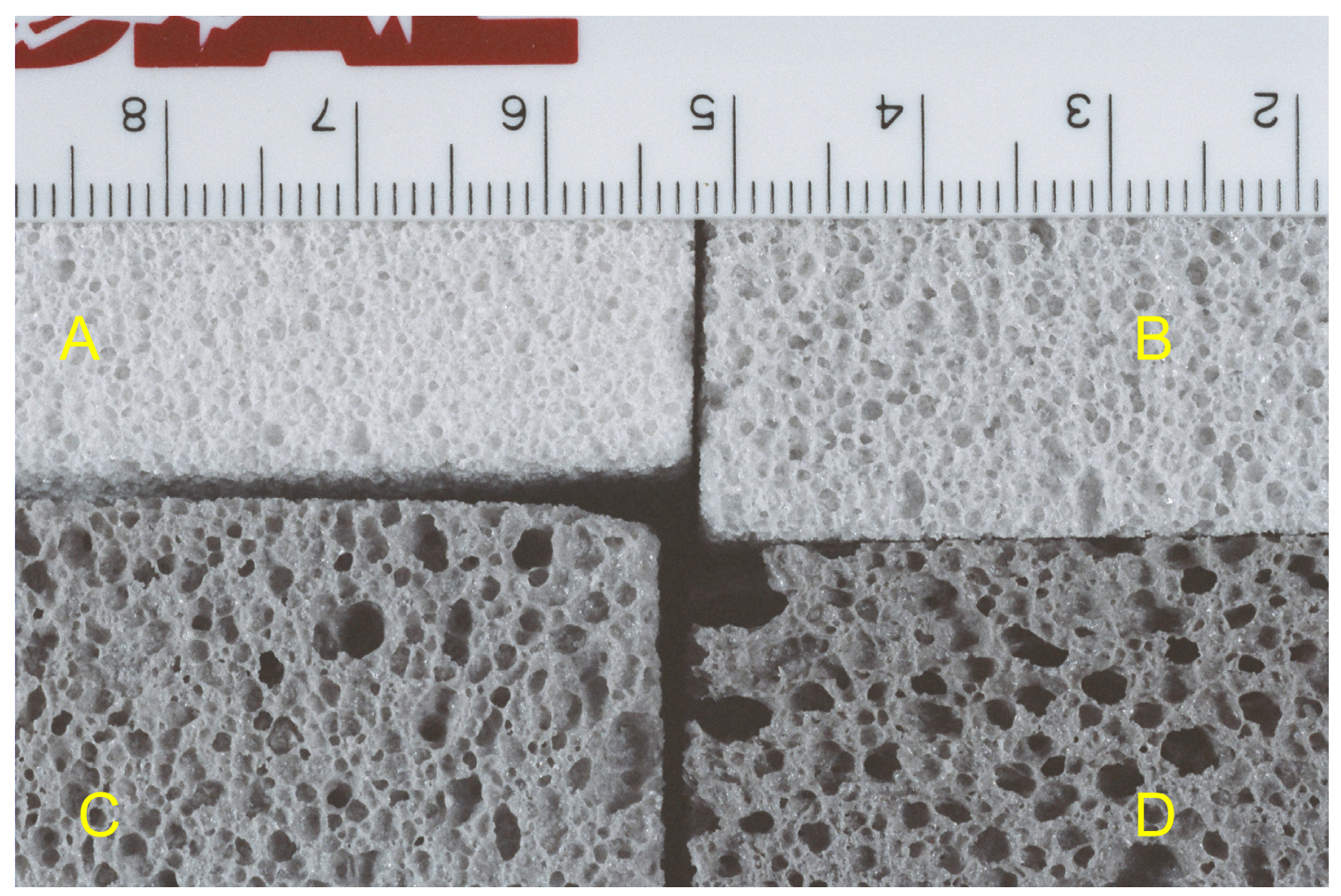

Figure 18. A close-up view of foamed glass blocks made with the addition of Wabash slag. The scale at the top of the picture is marked in centimeters and millimeters. The four compositions are:
A. $0.3 \%$ slag, $0.5 \% \mathrm{ZnO}, 0.85 \% \mathrm{CaCO}_{3}$
B. $1.0 \%$ slag, $0.5 \% \mathrm{ZnO}, 0.85 \% \mathrm{CaCO}_{3}$
C. $3.0 \%$ slag, $0.5 \% \mathrm{ZnO}, 0.85 \% \mathrm{CaCO}_{3}$
D. $5.0 \%$ slag, $0.5 \% \mathrm{ZnO}, 0.85 \% \mathrm{CaCO}_{3}$

Figure 18 shows a close-up (macro) photograph of foamed glasses made with varying amounts of Wabash slag. Figure 19 is an even closer photograph of the same four blocks. From these photographs, it can be seen that, with increasing loadings of Wabash slag: the foamed glass becomes darker. Also, the cells/voids/bubbles become larger, and their shapes seem to become more irregular (i.e., less spherical). This irregularity seems to be the result of the coalescence of two adjacent cells due to the rupture of the wall dividing them. 


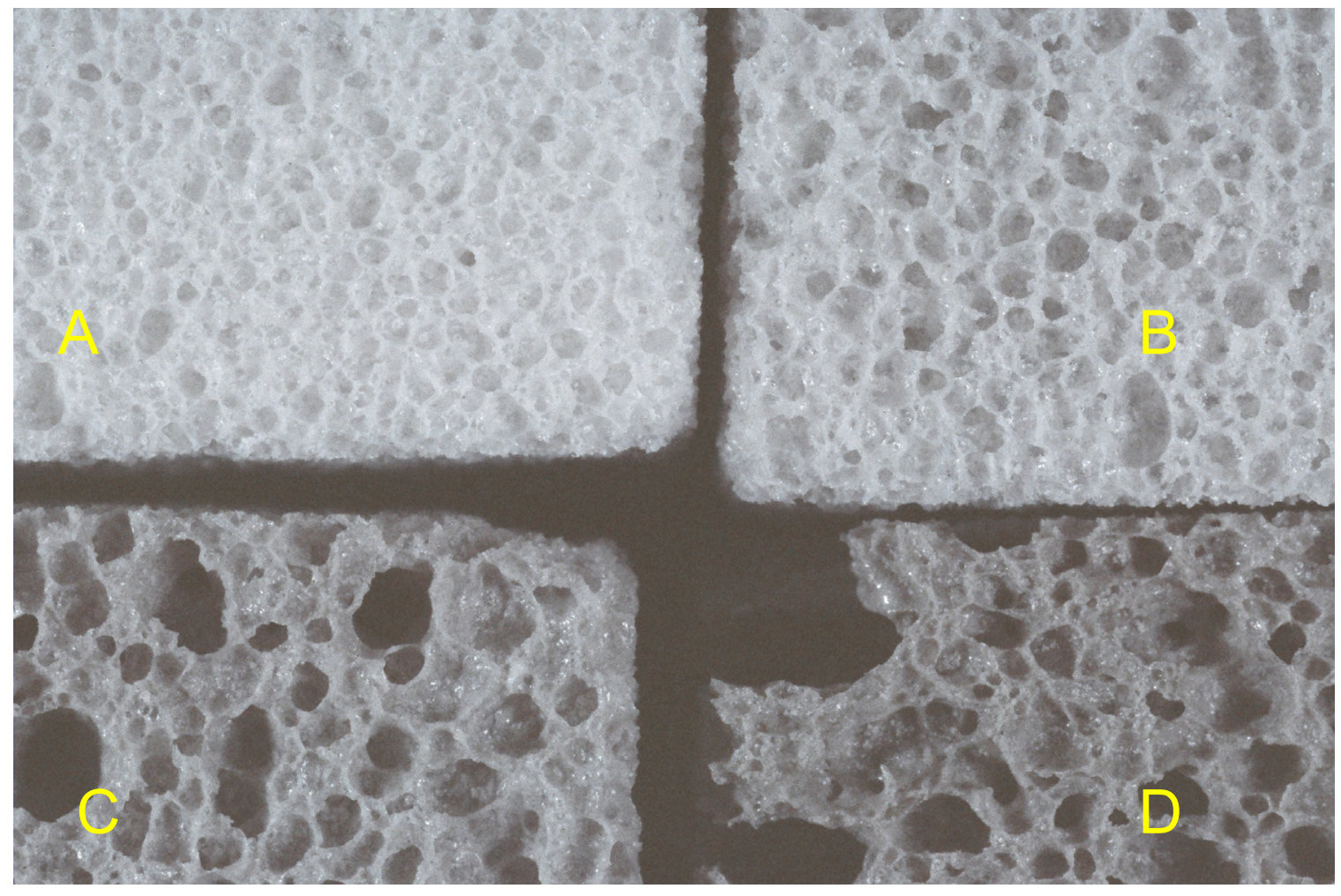

| Figure 19. An even closer view of the foamed glass blocks shown in the previous figure. The area shown in the picture covers a region that is approximately $2 \mathrm{~cm}$ high and $3 \mathrm{~cm}$ wide. The four compositions are:
A. $0.3 \%$ slag, $0.5 \% \mathrm{ZnO}, 0.85 \% \mathrm{CaCO}_{3}$
B. $1.0 \%$ slag, $0.5 \% \mathrm{ZnO}, 0.85 \% \mathrm{CaCO}_{3}$
C. $3.0 \%$ slag, $0.5 \% \mathrm{ZnO}, 0.85 \% \mathrm{CaCO}_{3}$
D. $5.0 \%$ slag, $0.5 \% \mathrm{ZnO}, 0.85 \% \mathrm{CaCO}_{3}$. 
Task 3. Evaluate health and safety implications of foaming agent / slag mixtures.

Composition analysis: The main instrument used by DIAL's analytical laboratory for composition analysis of slag and glass samples is the ICP (Inductively Coupled Plasma) instrument, a Perkin-Elmer Optima 4300 DV. Sample dissolution is accomplished by the sodium peroxide fusion process, developed at the Savannah River Site. [2]

The elemental compositions of both the Tampa and Wabash slags were determined via the sodium peroxide fusion/inductively coupled plasma technique described in the previous section. These results are given in Tables 4 and 5 below.

\begin{tabular}{|l|l|l|l|l|l|}
\hline \multicolumn{7}{|c|}{ Table 4. Composition of Tampa slag } \\
\hline Species & Mass \% & Species & Mass \% & Species & Mass \% \\
\hline $\mathrm{Al}_{2} \mathrm{O}_{3}$ & 15.28 & $\mathrm{Gd}_{2} \mathrm{O}_{3}$ & bd1* & $\mathrm{SeO}_{2}$ & bdl* \\
\hline $\mathrm{B}_{2} \mathrm{O}_{3}$ & 0.24 & $\mathrm{~K}_{2} \mathrm{O}$ & 0.30 & $\mathrm{SiO}_{2}$ & 38.94 \\
\hline $\mathrm{BaO}$ & 0.64 & $\mathrm{MgO}$ & 5.07 & $\mathrm{SnO}$ & 0.01 \\
\hline $\mathrm{CaO}$ & 20.78 & $\mathrm{MnO}$ & 0.04 & $\mathrm{SrO}$ & 0.30 \\
\hline $\mathrm{CdO}$ & 0.03 & $\mathrm{NiO}$ & 0.07 & $\mathrm{~V}_{2} \mathrm{O}_{5}$ & 0.09 \\
\hline $\mathrm{Cr}_{2} \mathrm{O}_{3}$ & 0.20 & $\mathrm{P}_{2} \mathrm{O}_{5}$ & 0.82 & $\mathrm{WO}_{2}$ & bd1* \\
\hline $\mathrm{Fe}_{2} \mathrm{O}_{3}$ & 5.50 & $\mathrm{SO}_{3}$ & bdl* & $\mathrm{ZnO}$ & 0.02 \\
\hline
\end{tabular}

\begin{tabular}{|l|l|l|l|l|l|}
\hline \multicolumn{7}{|c|}{ Table 5. Composition of Wabash slag } \\
\hline Species & Mass \% & Species & Mass \% & Species & Mass \% \\
\hline $\mathrm{Al}_{2} \mathrm{O}_{3}$ & 14.06 & $\mathrm{Gd}_{2} \mathrm{O}_{3}$ & bd1* & $\mathrm{SeO}_{2}$ & bd1* \\
\hline $\mathrm{B}_{2} \mathrm{O}_{3}$ & 0.22 & $\mathrm{~K}_{2} \mathrm{O}$ & 1.36 & $\mathrm{SiO}_{2}$ & 47.92 \\
\hline $\mathrm{BaO}$ & 0.06 & $\mathrm{MgO}$ & 1.33 & $\mathrm{SnO}_{2}$ & bd1* \\
\hline $\mathrm{CaO}$ & 3.08 & $\mathrm{MnO}$ & 0.06 & $\mathrm{SrO}$ & 0.04 \\
\hline $\mathrm{CdO}$ & $\mathrm{bd1} *$ & $\mathrm{NiO}$ & 0.76 & $\mathrm{~V}_{2} \mathrm{O}_{5}$ & 8.11 \\
\hline $\mathrm{Cr}_{2} \mathrm{O}_{3}$ & 0.13 & $\mathrm{P}_{2} \mathrm{O}_{5}$ & 0.11 & $\mathrm{WO}_{2}$ & 0.01 \\
\hline $\mathrm{Fe}_{2} \mathrm{O}_{3}$ & 10.02 & $\mathrm{SO}_{3}$ & 2.91 & $\mathrm{ZnO}$ & 0.13 \\
\hline
\end{tabular}

* bdl - below detection limit.

Because the dissolution method adds sodium, the sodium content of these slags had to be measured via a separate analysis. Each slag contains roughly 2 per cent sodium.

We draw attention to the high vanadium content of the Wabash slag. Vanadium is listed under RCRA. Foamed glass made from this slag would probably (we haven't tested it yet) pass a leachability test, even so, the presence of a RCRA metal would be undesirable in a consumer product. However, we note that vanadium is usually not found in high concentrations in coal slag.

During the current reporting period, samples of foamed glass were tested according to the TCLP (Toxicity Characteristic Leaching Procedure) procedure. The tests were performed 
in the analytical laboratories at DIAL/MSU. Two foamed glasses were selected for testing; the first containing 5\% Tampa slag and the second containing 7.5\% Wabash slag. These slag loadings are slightly higher than those which make acceptable foamed glass; we felt that materials with the highest slag content would be most likely to leach hazardous elements and thus would provide a more stringent test. Three samples of each type of foamed glass were tested.

The TCLP test measures whether potentially harmful elements will remain chemically bound in an insoluble form, or if they are mobile and will leach out. In the TCLP test, the material is crushed into small pieces and these pieces are soaked in an acidic solution. The liquid is then analyzed for harmful elements. In the analytical laboratory at DIAL/MSU, mercury was analyzed by cold-vapor atomic absorption, and the remaining elements were analyzed by an inductively -coupled plasma instrument.

The TCLP test is mandated by the EPA for testing wastes. If hazardous elements do not leach from a waste material, then it is nonhazardous and can be placed in an ordinary landfill.

Table 6 shows the TCLP results from the foamed glass with 5\% Tampa slag. Table 7 gives the TCLP results for a foamed glass made with 7.5\% Wabash slag. For comparison, Table 8 gives the acceptable limits. 


\begin{tabular}{|l|l|l|l|l|l|l|l|}
\hline \multicolumn{7}{|c|}{ Table 6. TCLP results from foamed glass made with 5\% Tampa slag. } \\
\hline Element & TCLP 1 & TCLP 2 & TCLP 3 & Average & Units & $\begin{array}{l}\text { Standard } \\
\text { deviation }\end{array}$ & $\begin{array}{l}\text { RSD }^{*} \\
(\%)\end{array}$ \\
\hline Silver & 0.015 & 0.015 & 0.015 & 0.015 & $\mathrm{mg} / \mathrm{L}$ & 0.000 & 0.00 \\
\hline Arsenic & 0.005 & 0.004 & 0.006 & 0.005 & $\mathrm{mg} / \mathrm{L}$ & 0.001 & 20.0 \\
\hline Barium & 0.588 & 0.553 & 0.647 & 0.596 & $\mathrm{mg} / \mathrm{L}$ & 0.048 & 7.97 \\
\hline Cadmium & 0.00 & 0.00 & 0.00 & 0.00 & $\mathrm{mg} / \mathrm{L}$ & 0.000 & - \\
\hline Chromium & 0.041 & 0.030 & 0.022 & 0.031 & $\mathrm{mg} / \mathrm{L}$ & 0.010 & 30.8 \\
\hline Lead & 0.005 & 0.004 & 0.005 & 0.005 & $\mathrm{mg} / \mathrm{L}$ & 0.001 & 12.4 \\
\hline Selenium & 0.00 & 0.00 & 0.00 & 0.00 & $\mathrm{mg} / \mathrm{L}$ & 0.000 & - \\
\hline Vanadium & 0.003 & 0.00 & 0.001 & 0.001 & $\mathrm{mg} / \mathrm{L}$ & 0.002 & 115 \\
\hline Mercury & 0.00 & 0.120 & 0.00 & 0.040 & $\mu \mathrm{g} / \mathrm{L}$ & 0.069 & 173 \\
\hline * Relative Standard Deviation
\end{tabular}

\begin{tabular}{|l|l|l|l|l|l|l|l|}
\hline \multicolumn{7}{|c|}{ Table 7. TCLP results from foamed glass made with 7.5\% Wabash slag. } \\
\hline Element & TCLP 1 & TCLP 2 & TCLP 3 & Average & Units & $\begin{array}{l}\text { Standard } \\
\text { deviation }\end{array}$ & $\begin{array}{l}\text { RSD } \\
(\%)\end{array}$ \\
\hline Silver & 0.015 & 0.016 & 0.016 & 0.016 & $\mathrm{mg} / \mathrm{L}$ & 0.001 & 3.69 \\
\hline Arsenic & 0.029 & 0.024 & 0.027 & 0.027 & $\mathrm{mg} / \mathrm{L}$ & 0.003 & 9.44 \\
\hline Barium & 0.053 & 0.055 & 0.057 & 0.055 & $\mathrm{mg} / \mathrm{L}$ & 0.002 & 3.64 \\
\hline Cadmium & 0.00 & 0.00 & 0.00 & 0.00 & $\mathrm{mg} / \mathrm{L}$ & 0.000 & - \\
\hline Chromium & 0.009 & 0.015 & 0.019 & 0.014 & $\mathrm{mg} / \mathrm{L}$ & 0.005 & 35.1 \\
\hline Lead & 0.006 & 0.004 & 0.005 & 0.005 & $\mathrm{mg} / \mathrm{L}$ & 0.001 & 20.0 \\
\hline Selenium & 0.00 & 0.00 & 0.00 & 0.00 & $\mathrm{mg} / \mathrm{L}$ & 0.000 & - \\
\hline Vanadium & 1.03 & 0.995 & 1.02 & 1.01 & $\mathrm{mg} / \mathrm{L}$ & 0.017 & 1.66 \\
\hline Mercury & 0.00 & 0.00 & 0.00 & 0.00 & $\mu \mathrm{g} / \mathrm{L}$ & 0.000 & - \\
\hline * Relative Standard Deviation & \multicolumn{7}{|l|l|l|l|}{} \\
\hline
\end{tabular}




\begin{tabular}{|l|l|l|}
\hline \multicolumn{2}{|c|}{ Table 8. Maximum allowable levels. } \\
\hline Element & RCRA $^{*}$ limit $(\mathrm{mg} / \mathrm{L})$ & $\mathrm{UTS}^{\dagger}$ limit $(\mathrm{mg} / \mathrm{L})$ \\
\hline Silver & 5.0 & 0.14 \\
\hline Arsenic & 5.0 & 5.00 \\
\hline Barium & 100.0 & 21.0 \\
\hline Cadmium & 1.0 & 0.11 \\
\hline Chromium & 5.0 & 0.60 \\
\hline Lead & 5.0 & 0.75 \\
\hline Selenium & 1.0 & 5.7 \\
\hline Vanadium & NA & 1.60 \\
\hline Mercury & $200 \mu \mathrm{g} / \mathrm{L}$ & $25 \mu \mathrm{g} / \mathrm{L}$ \\
\hline * Resource Recovery and Recovery Act \\
\hline$\dagger$ Universal Treatment Standard \\
\hline
\end{tabular}

These results indicate that the glass foam made using either type of slag, Tampa or Wabash, will not be hazardous to handle or to dispose of. 
Task 4. Measure abrasion resistance, thermal conductivity, and softening point.

Approach. Earthstone's products are currently marketed as abrasives. The drywall product, for example, is sold in building supply stores to be used for sanding joints when finishing drywall. Therefore, Earthstone routinely tests their products for abrasion resistance. Attrition is measured by a commercial system that passes a $47.6 \times 73.0 \times 197$. $\mathrm{mm}(1.875 \times 2.875 \times 3.875 \mathrm{inch})$ sample (the $73.0 \times 197 \mathrm{~mm}$ surface is face down $)$ across a silicon carbide plate 50 times, at 0.36 meters ( 14 inches) per stroke. The stone bears a $2.27 \mathrm{~kg}$ ( 5 pound) weight during the test to apply a normal force to the surface being abraded. The samples are weighed before and after to determine the amount of material lost. The amount of material lost is reported as a percentage of the original weight of the sample.

The thermal conductivity of the foamed glass was tested. Slabs of foam glass measuring $0.305 \mathrm{~m} \times 0.305 \mathrm{~m} \times 25.4 \mathrm{~mm}(12 \times 12 \times 1$ inches $)$ were cut. These were sent to an outside testing laboratory (Anter Laboratories, in Pittsburgh, PA) for testing according to ASTM Method C518. The thermal conductivity was measured at nominal room temperature (25 ${ }^{\circ} \mathrm{C}$, or $\left.77^{\circ} \mathrm{F}\right)$ ).

The softening point glass transition temperature was measured by the Differential Scanning Calorimeter (DSC) instrument. The DSC analyzer measures the amount of heat required to increase the temperature of the sample. DSC results can indicate phase changes and glass transitions. The DSC instrument heats the sample being tested and an inert reference material. The instrument applies extra heat to the cooler of the two to equalize any temperature difference. The instrument output is proportional to the amount of differential heating required.

Results. The results of the abrasion resistance (attrition) tests are shown in Table 9. The addition of Wabash slag made a substantial improvement in the abrasion resistance of the foamed glass product.

The thermal conductivity results reported by Anter Laboratories are shown in Table 10. The effect of the additives is curious. At lower concentrations of slag, the thermal conductivity is lower than for the drywall product with no additives, but, at the highest slag loading, the thermal conductivity is higher. Possibly, the additional calcium carbonate is creating more gas bubbles, and hence a lower thermal conductivity, but this effect is eventually overcome by the addition of more slag. 


\begin{tabular}{|c|c|c|c|c|c|}
\hline \multicolumn{6}{|c|}{ Table 9. Results of abrasion resistance tests. } \\
\hline Composition & Sample \# & $\begin{array}{l}\text { Initial mass } \\
\text { (grams) }\end{array}$ & \begin{tabular}{|l}
$\begin{array}{l}\text { Final mass } \\
\text { (grams) }\end{array}$ \\
\end{tabular} & \begin{tabular}{|l}
$\begin{array}{l}\text { Lost mass } \\
\text { (grams) }\end{array}$ \\
\end{tabular} & $\begin{array}{l}\text { Per cent } \\
\text { attrition }\end{array}$ \\
\hline $0.3 \%$ slag & 11 & 60.4 & 41.0 & 19.4 & 32.11 \\
\hline $0.3 \%$ slag & 2 & 62.3 & 44.8 & 17.5 & 28.08 \\
\hline $0.3 \%$ slag & 3 & 61.7 & 43.5 & 18.2 & 29.49 \\
\hline $0.3 \%$ slag & 4 & 61.3 & 44.8 & 16.5 & 26.91 \\
\hline $0.3 \%$ slag & 5 & 61.0 & 43.7 & 17.3 & 28.60 \\
\hline \multicolumn{5}{|c|}{$0.3 \%$ slag average } & 29.038 \\
\hline $1.0 \%$ slag & $\mid 1$ & 64.5 & 50.0 & 14.5 & 22.48 \\
\hline $1.0 \%$ slag & 2 & 62.1 & 46.1 & 16.0 & 25.76 \\
\hline $1.0 \%$ slag & 3 & 63.2 & 50.6 & 12.6 & 19.93 \\
\hline $1.0 \%$ slag & 4 & 64.0 & 54.0 & 10.0 & 15.62 \\
\hline $1.0 \%$ slag & 5 & 63.5 & 50.4 & 13.1 & 20.62 \\
\hline \multicolumn{5}{|c|}{$1.0 \%$ slag average } & 20.882 \\
\hline $3.0 \%$ slag & 1 & 67.9 & 59.0 & 8.9 & 13.10 \\
\hline $3.0 \%$ slag & 2 & 65.7 & 57.7 & 8.0 & 12.17 \\
\hline $3.0 \%$ slag & 3 & 71.2 & 62.7 & 8.5 & 11.93 \\
\hline $3.0 \%$ slag & 4 & 66.9 & 58.8 & 8.1 & 12.10 \\
\hline $3.0 \%$ slag & 5 & 66.5 & 58.9 & 7.6 & 11.42 \\
\hline \multicolumn{5}{|c|}{$3.0 \%$ Wabash slag average } & 12.144 \\
\hline $5.0 \%$ slag & 1 & 118.0 & 114.3 & 3.7 & 3.13 \\
\hline $5.0 \%$ slag & 2 & 116.4 & 111.7 & 4.7 & 4.03 \\
\hline $5.0 \%$ slag & 3 & 109.6 & 105.2 & 4.4 & 4.01 \\
\hline $5.0 \%$ slag & 4 & 112.8 & 108.1 & 4.7 & 4.16 \\
\hline $5.0 \%$ slag & 5 & 116.7 & 113.1 & 3.6 & 3.08 \\
\hline \multicolumn{5}{|c|}{$5.0 \%$ slag average } & 3.682 \\
\hline
\end{tabular}

\begin{tabular}{|l|ll|}
\hline \multicolumn{3}{|c|}{ Table 10. Results of thermal conductivity testing. } \\
\hline Composition & \multicolumn{2}{|l|}{ Thermal conductivity at $25^{\circ} \mathrm{C}\left(77^{\circ} \mathrm{F}\right)}$, \\
& $\mathrm{W} /(\mathrm{m} \cdot \mathrm{K})$ & $\left(\mathrm{btu} /\left(\mathrm{hr} \cdot \mathrm{ft} \cdot{ }^{\circ} \mathrm{F}\right)\right)$ \\
\hline Drywall, no additives, sample 1 & 0.088 & $(0.051)$ \\
\hline Drywall, no additives, sample 2 & 0.084 & $(0.049)$ \\
\hline Drywall, no additives, sample 3 & 0.087 & $(0.050)$ \\
\hline $1 \%$ slag, $0.5 \% \mathrm{ZnO}, 0.85 \% \mathrm{CaCO}_{3}$ & 0.0792 & $(0.0458)$ \\
\hline $3 \%$ slag, $0.5 \% \mathrm{ZnO}, 0.85 \% \mathrm{CaCO}_{3}$ & 0.0794 & $(0.0459)$ \\
\hline $5 \%$ slag, $0.5 \% \mathrm{ZnO}, 0.85 \% \mathrm{CaCO}_{3}$ & 0.0912 & $(0.0527)$ \\
\hline
\end{tabular}




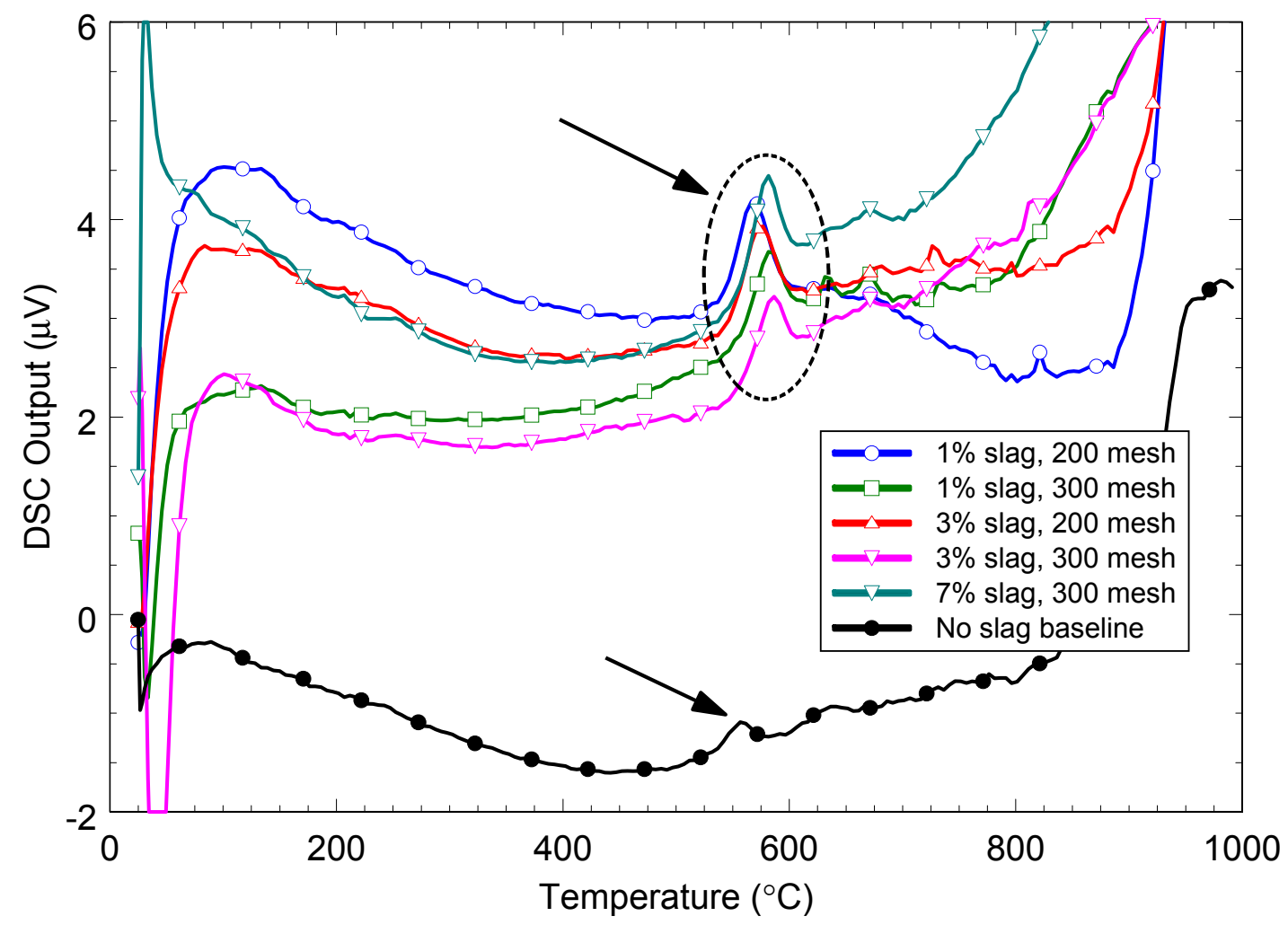

Figure 20. Differential Scanning Calorimeter (DSC) results for samples of foamed glass with varying quantities of Wabash slag, and a baseline case consisting of the drywall product with no slag added.

Figure 20 shows DSC results (thermograms) for foamed glass made from the Earthstone drywall batch with varying amounts of Wabash slag added. Also shown is a baseline curve of the drywall product with no slag added.. This thermogram depicts the behavior of samples as they are heated (linear ramp) from ambient to a maximum temperature of $1000^{\circ} \mathrm{C}\left(1830^{\circ} \mathrm{F}\right)$. For these thermograms, the instrument output is not given in energy units, such as Watts per milligram, instead, the raw detector output in microvolts is plotted as a function of temperature. The sign of the detector output is such that an exothermic process produces a negative (downward) voltage, and an endothermic process produces a positive (upward) voltage.

In Figure 20, the arrows point to a peak just below $600^{\circ} \mathrm{C}\left(1110^{\circ} \mathrm{F}\right)$. This peak indicates an endothermic process corresponding to the glass transition temperature $\left(\mathrm{T}_{\mathrm{g}}\right)$ of the material. The foam glass is made from cullet of ordinary window glass which has a $T_{g}$ of about $550{ }^{\circ} \mathrm{C}\left(1020^{\circ} \mathrm{F}\right)$ and a softening temperature of about $730^{\circ} \mathrm{C}\left(1350{ }^{\circ} \mathrm{F}\right)$. The addition of the slag appears to increase $\mathrm{T}_{\mathrm{g}}$ in the range of about 6 to 25 degrees Celsius. As the current processing is done at about $900^{\circ} \mathrm{C}\left(1650^{\circ} \mathrm{F}\right)$, increasing the softening temperature to about $750^{\circ} \mathrm{C}\left(1380^{\circ} \mathrm{F}\right)$ is not expected to be a cause for concern. The 
variations observed are slight and are of no consequence in processing the material. The results are summarized in Table 11.

\begin{tabular}{|l|ll|}
\hline \multicolumn{3}{|c|}{ Table 11. Glass transition temperatures. } \\
\hline Composition & \multicolumn{3}{c|}{ Glass transition temperature, ${ }^{\circ} \mathrm{C}\left({ }^{\circ} \mathrm{F}\right)$} \\
\hline Dry wall, no slag & 560.8 & $(1041)$ \\
\hline 1\% Wabash slag, 200 series glass & 566.6 & $(1052)$ \\
\hline 1\% Wabash slag, 300 series glass & 583.0 & $(1081)$ \\
\hline $3 \%$ Wabash slag, 200 series galss & 571.5 & $(1061)$ \\
\hline $3 \%$ Wabash slag, 300 series glass & 584.6 & $(1084)$ \\
\hline $7 \%$ Wabash slag, 300 series glass & 586.1 & $(1087)$ \\
\hline
\end{tabular}

A glass material that undergoes an increase in thermal energy will convert from behavior as a solid to behavior as a liquid. This conversion occurs without change of state reactions and is considered a steady transitory change. The conversion is bounded by the upper and lower glass transition temperatures. The lower temperature is defined as the strain point and the upper transition temperature is the annealing point. Above the annealing point, as the glass continues to heat, it will lose the ability to hold shape - this is defined as the softening point $\left(10^{7.65}\right.$ poise viscosity). At this point, the glass can no longer be physiochemically defined as a solid material. 
Task 5. Abrasive and adhesive properties of foam slags will be tested.

The abrasive properties were tested and the discussion of those results is contained in the previous section of this report. (By mistake, testing abrasive properties was included under both task 4 and task 5.)

Adhesion testing was conducted informally. Valley Industrial adhesive papers were incorporated into the testing program and provided sufficient adhesion to obviate quantitative testing (two failed apparatus indicated more than sufficient bonding). Again, as the incorporation of slag to glass was less than $7 \%$, the physical and chemical properties for adhesion were not impacted by the slag. 


\section{Phase 3 Quantification of Slag Foam Process Economics}

Task 1 Evaluate slag foam production cost - including cost impact of slag incorporation versus current industrial practice.

Task 2 Determine impact of the inclusion of slag on foam production process.

Task 3 Evaluate slag proximity to foam production locations and relative comminution cost of slag.

Our objective is to provide an objective analysis of the cost impact/benefit of substituting coal gasifier slag for powdered glass in the production of Earthstone glass foam.

Incorporating slag may have performance advantages, but it is necessary to determine the impact on Cost of Goods Sold (COGS) to the company in order to provide balanced, decision-quality data.

Upon determination of 1) the minimum slag content to impact any physical property and 2) the maximum slag content that can be incorporated, the impact of adding slag to the raw material processing and foam production properties was reviewed. There were no obvious detrimental impacts to the processing equipment or foaming process. Likewise, the TCLP results indicated no increased risk to workers or consumers. Effectively, the powdered slag can be treated in a manner similar to common powdered glass. Earthstone is committed to safe, environmentally friendly production operations and products. This review was essential prior to economic analysis.

The effective minimum content of slag that impacts product attrition (the rate at which the abrasive breaks down under a given load and speed against a standard substrate) was determined to be 0.3 weight percent. The maximum effective loading which yields a sufficient foam rise was determined to be 5 weight percent. Seven (7) weight percent was successfully incorporated - but this loading did not yield sufficient foam rise to be considered economical to produce.

The test batches of glass foam that were produced as part of this study used furnace heating profiles that were identical to those used by Earthstone for their commercial production of glass foam. At slag loadings up to 3 per cent, the density of the glass foam remains nearly constant; therefore, the amount of batch that is loaded into a sagger, and the resulting volume of glass foam, will remain the same. Therefore, at slag loadings up to 3 per cent, the production process, the quantity of batch required, and the yield of glass foam will remain roughly the same.

The only effective impact to process economics was determined to be the relative cost differential between powdered glass and powdered slag. All slag incorporated must be ground to the same particle size (nominally 10 micron particle median diameter) as the glass. It was not possible to produce a coherent foam with particles larger than 20 microns median particle diameter. 
The impact of foam addition is shown in Tables 12,13, and 14, three spreadsheets that calculate the difference between Earthstone's basic drywall product, and with additions of 1 and 3 weight percent powdered slag. The slag is assumed to have an as-received cost of $\$ 0.04$ per pound. This value is derived from the standard cost of grinding vitreous material to 10 microns, nominal shipping of 750 miles, and no tipping fee at the source. This results in the lowest appreciable cost possible. The basic assumption are that no impact on yield (functions of foam rise and consistency) is derived from experimental observation. Any increase beyond 3 percent would result in a lower rise, denser foam with fewer blocks per mass of batch.

The results indicate that each weight percent of slag incorporated reduces block cost slightly over $\$ 0.001$. A nominal production year yields between 300,000 and 400,000 blocks. The resulting $\$ 300$ to $\$ 400$ in savings is relatively inconsequential. What is consequential is improvement in product quality due to the more than $2 \times$ reduction in attrition rate observed at the $3 \%$ level.

\begin{tabular}{|l|l|l|l|}
\hline \multicolumn{4}{|c|}{$\begin{array}{l}\text { Table 12. Materials cost of manufacturing the drywall } \\
\text { glass foam product (baseline). }\end{array}$} \\
\hline Material & Cost $(\$ / 1 b)$ & Amount required (\%) & Cost (\$/Sagger) \\
\hline Glass & $\$ 0.21$ & & $\$ 0.000$ \\
\hline Calcium Carbonate & $\$ 0.15$ & & $\$ 0.000$ \\
\hline Zinc Oxide & $\$ 0.90$ & & $\$ 0.000$ \\
\hline Silicon Carbide & $\$ 2.08$ & & $\$ 0.000$ \\
\hline Sand & $\$ 0.05$ & & $\$ 0.000$ \\
\hline Iron Oxide & $\$ 0.85$ & & $\$ 0.000$ \\
\hline Slag & $\$ 0.04$ & & $\$ 0.000$ \\
\hline Glass (300 Series, SM) & $\$ 0.26$ & $99.25 \%$ & $\$ 3.556$ \\
\hline Calcium Carbonate (325) & $\$ 0.20$ & $0.75 \%$ & $\$ 0.021$ \\
\hline Total & \multicolumn{3}{l}{$\$ 3.576$} \\
\hline Cost per Block & $100.00 \%$ & $\$ 0.149$ \\
\hline $\begin{array}{l}\text { Calculated assuming that 11 pounds of batch are required per sagger, and that each } \\
\text { sagger makes 24 foam blocks, with a useful yield of 80\%. }\end{array}$ \\
\hline
\end{tabular}




\begin{tabular}{|l|l|l|l|}
\hline \multicolumn{4}{|c|}{$\begin{array}{c}\text { Table 13. Materials cost of manufacturing the drywall } \\
\text { glass foam product with 1\% slag added. }\end{array}$} \\
\hline Material & Cost $(\$ / 1 \mathrm{~b})$ & Amount required (\%) & Cost $(\$ /$ Sagger) \\
\hline Glass & $\$ 0.21$ & & $\$ 0.000$ \\
\hline Calcium Carbonate & $\$ 0.15$ & & $\$ 0.000$ \\
\hline Zinc Oxide & $\$ 0.90$ & & $\$ 0.000$ \\
\hline Silicon Carbide & $\$ 2.08$ & & $\$ 0.000$ \\
\hline Sand & $\$ 0.05$ & & $\$ 0.000$ \\
\hline Iron Oxide & $\$ 0.85$ & & $\$ 0.000$ \\
\hline Slag & $\$ 0.04$ & $1.00 \%$ & $\$ 0.006$ \\
\hline Glass (300 Series, SM) & $\$ 0.26$ & $98.25 \%$ & $\$ 3.520$ \\
\hline Calcium Carbonate (325) & $\$ 0.20$ & $0.75 \%$ & $\$ 0.021$ \\
\hline Total & & $100.00 \%$ & $\$ 3.546$ \\
\hline Cost per Block & & & $\$ 0.148$ \\
\hline $\begin{array}{l}\text { Calculated assuming that 11 pounds of batch are required per sagger, and that each } \\
\text { sagger makes 24 foam blocks, with a useful yield of 80\%. }\end{array}$ \\
\hline
\end{tabular}

\begin{tabular}{|l|l|l|l|}
\hline \multicolumn{4}{|c|}{$\begin{array}{l}\text { Table 14. Materials cost of manufacturing the drywall } \\
\text { glass foam product with 3\% slag added. }\end{array}$} \\
\hline Material & Cost $\$ / 1 \mathrm{lb})$ & Amount required (\%) & Cost (\$/Sagger) \\
\hline Glass & $\$ 0.21$ & & $\$ 0.000$ \\
\hline Calcium Carbonate & $\$ 0.15$ & & $\$ 0.000$ \\
\hline Zinc Oxide & $\$ 0.90$ & & $\$ 0.000$ \\
\hline Silicon Carbide & $\$ 2.08$ & & $\$ 0.000$ \\
\hline Sand & $\$ 0.05$ & & $\$ 0.000$ \\
\hline Iron Oxide & $\$ 0.85$ & & $\$ 0.000$ \\
\hline Slag & $\$ 0.04$ & $3.00 \%$ & $\$ 0.017$ \\
\hline Glass (300 Series, SM) & $\$ 0.26$ & $96.25 \%$ & $\$ 3.448$ \\
\hline Calcium Carbonate (325) & $\$ 0.20$ & $0.75 \%$ & $\$ 0.021$ \\
\hline Total & & $100.00 \%$ & $\$ 3.485$ \\
\hline Cost per Block & & & $\$ 0.145$ \\
\hline $\begin{array}{l}\text { Calculated assuming that 11 pounds of batch are required per sagger, and that each } \\
\text { sagger makes 24 foam blocks, with a useful yield of 80\%. }\end{array}$ \\
\hline
\end{tabular}




\section{CONCLUSIONS}

We have successfully incorporated gasifier slag into foamed glass. The slag does not simply act as a filler, but actually improves the properties of the material.

The best results were obtained with slag from the Wabash River Project. Up to 7\% by weight of slag could be incorporated into the foamed glass. At loadings up to about $3 \%$, the density of the final foam product remains roughly constant, indicating that the porosity of the foam is unaffected. As the slag loading is increased to $5 \%$ and then to $7 \%$, the product density begins to increase, indicating that the higher slag loading is interfering with the amount of rise we can achieve. Microscopic examination of these foams revels the presence of small particles in the glass matrix, suggesting that the slag particles do not melt at the foaming temperatures we used. Research into foam stability (e.g., [3]) indicates that solid particles can destabilize the liquid film between gas bubbles, causing the film to break and ultimately destroying the foam. This is consistent with the observed trend of decreasing porosity as the slag loading increases. Also, the increase in cell size with increasing slag loading, illustrated in Figures 18 and 19, is consistent with this hypothesis.

Earthstone International currently markets foamed glass as an abrasive. For this application, the optimum slag loading is about $3 \%$ by weight. This loading is low enough that the amount of rise is unaffected, thus ensuring that the volumetric yield of product remains the same. However, this modest slag loading improves the abrasion resistance by better than a factor of two, thus substantially improving the product. This level of slag addition would have no effect on the production process, and actually decreases the cost of production, albeit by an insignificant amount.

We have developed a new material that is mechanically strong enough for new applications. In terms of physical properties, the tensile strength of the $7 \%$ material is more than $40 \%$ higher than the base material and demonstrates that the reinforced foam glass could be used as a building material. The compressive strength testing showed that the foamed glass really doesn't "fail" under compressive loads, but merely crushes.

The thermal conductivity and softening point of the foamed glass and slag reinforced foam glass were very similar. The adhesive properties of the slag-reinforced foamed glass were no different than that of the base material. An evaluation of the health and safety implications of foaming agent and slag mixtures showed that the material will pass the TCLP and so will not be regarded as a hazardous material.

Although this application does not require a large amount of the waste material, we believe that the slag-reinforced foamed glass is a significant improvement over the base material. 


\section{RECOMMENDATIONS FOR FUTURE INVESTIGATIONS}

We have developed a new material that is mechanically strong enough for new applications. The addition of the waste material (slag) adds both strength and abrasion resistance to the foamed glass. The initial application of this new material would be as insulation for buildings. The additional ruggedness of the foamed glass will allow the manufacture of monolithic pieces of appropriate size for insulating walls of (for instance) houses.

Future work on this system could develop even stronger materials and thus lead to wider applications. We have already been approached by a potential customer looking to use the stronger foamed glass product as a part of a system of protective armor. The brittle fracture of the foamed glass provides an energy absorbing barrier that can ameliorate the impact of rocket propelled grenades and similar projectiles. The success of the current project bodes well for this and other potential applications.

Earthstone International, as a commercial manufacturer of foamed glass products, is particularly interested in expanding their product line. The results of this project will allow them some incremental improvement in their current line of abrasive materials. Further studies which would lead to much stronger and more abrasive resistant materials would provide them the opportunity to move into a wider range of products, as described above. 


\section{REFERENCES}

1. Scherer, George W., Relaxation in Glass and Composites, Wiley, 1986, pp. 134135, 162-174.

2. Coleman, C. J., Bibler, N. E., and Dewberry, R. A., "Analyses of high-level radioactive glasses and sludges at the Savannah River Site," WSRC-RP-89-960. (Also presented at Waste Management '90.)

3. Aveyard, R., Binks, B. P., Clint, J. H., and Fletcher, P. D. I., "Foams and emulsions: Their stability and breakdown by solid particles and liquid droplets. The colloid chemistry of a dog's breakfast," Chapter II in Foams and Emulsions, edited by J. F. Sadoc and N. Rivier, NATO Advanced Science Institute Series, Series E: Applied Sciences, Volume 355, Kluwer, 1999.

4. Zehe, Michael J., Gordon, Sanford, and McBride, Bonnie J. "CAP: A Computer Code for Generating Tabular Thermodynamic Functions from NASA Lewis Coefficients," NASA/TP-2001-210959/REV1, NASA Glenn Research Center, Cleveland, Ohio, February 2002.

5. U. S. Standard Atmosphere, described in Avallone, Eugene A. and Baumeister, Theodore, III, Marks' Standard Handbook for Mechanical Engineers, 9th edition, McGraw-Hill, 1986, page 6-10.

6. 1976 U. S. Standard Atmosphere, described in White, Frank M., Fluid Mechanics, 5th edition, McGraw-Hill, 2003, equation 2.27, page 72. 


\section{APPENDIX A \\ Equilibrium Calculation of the Thermal \\ Decomposition of Calcium Carbonate}

The experimental production of foamed glass, in small laboratory batches, is done in small, electrically heated furnaces in DIAL's laboratories. Earthstone has sent DIAL the batch mixtures they use for commercial production of foam glass.

We consistently find that we must add additional foaming agent (powdered limestone, $\mathrm{CaCO}_{3}$ ) to obtain an adequate amount of rise in our laboratory furnaces. The temperature calibrations of these furnaces were checked, and found to be acceptable.

Our next guess was that the altitude difference might be significant. Earthstone's current production facilities, near Santa Fe, New Mexico, are approximately 7,500 feet above sea level, while DIAL's laboratories in Mississippi are nearly at sea level. If the altitude were to be responsible for this effect we see, this would potentially be of great importance to Earthstone, since they are planning to build additional production facilities in other locations.

The foaming action is due to the thermal decomposition of the calcium carbonate according to the reaction:

$$
\mathrm{CaCO}_{3} \leftrightarrow \mathrm{CaO}+\mathrm{CO}_{2}
$$

where the carbon dioxide is evolved as a gas, forming bubbles in the glass.

The DSC results (see Figure 1) show that this reaction is not equilibrated; that kinetics are important in determining the rate of carbon dioxide evolution. However, we decided to perform a simple equilibrium calculation just to see how large a difference altitude would make.

Thermodynamic properties for $\mathrm{CaCO}_{3}(\mathrm{cr}, 1), \mathrm{CaO}$ (cr,l) and $\mathrm{CO}_{2}$ (g) were obtained using the CAP program and thermodynamic database developed by NASA. [4] The online interface to CAP, ThermoBuild (http://cea.grc.nasa.gov/), was used to generate tables of thermodynamic properties for these species, at $10 \mathrm{~K}$ temperature intervals from 300 to $2000 \mathrm{~K}$.

These tables were imported into a Microsoft Excel spreadsheet. From the tabulated values of enthalpy $(\mathrm{H})$ and entropy $(\mathrm{S})$, a column containing the Gibbs free energy $(\mathrm{G}=\mathrm{H}$ $\mathrm{TS})$ was computed. Then, the change in Gibbs free energy $(\Delta \mathrm{G})$ was computed for the reaction $\mathrm{CaCO}_{3} \rightarrow \mathrm{CaO}+\mathrm{CO}_{2}$. From the $\Delta \mathrm{G}$ of this reaction, the equilibrium constant was found from $\mathrm{k}=\exp (-\Delta \mathrm{G} / \mathrm{RT})$, where $\mathrm{R}$ is the ideal gas constant and $\mathrm{T}$ is the temperature in Kelvin. In this way, the equilibrium constant $\mathrm{k}$ was tabulated at $10 \mathrm{~K}$ temperature intervals from 300 to $2000 \mathrm{~K}$. 
By definition,

$$
\mathrm{k}=\left(\mathrm{a}_{\mathrm{CaO}} \cdot \mathrm{a}_{\mathrm{CO} 2}\right) / \mathrm{a}_{\mathrm{CaCO}}
$$

where $\mathrm{a}_{\mathrm{CaO}}$ is the activity of $\mathrm{CaO}, \mathrm{a}_{\mathrm{CO} 2}$ is the activity of $\mathrm{CO}_{2}$, and $\mathrm{a}_{\mathrm{CaCO}}$ is the activity of $\mathrm{CaCO}_{3}$.

$\mathrm{CO}_{2}$ is a gas, so its activity is equal to its partial pressure, $\mathrm{P}_{\mathrm{CO} 2}$, in atmospheres. $\mathrm{CaO}$ and $\mathrm{CaCO}_{3}$ are condensed phases (either crystalline or liquid). If they were present as pure substances, their activities would be one. However, we are interested in the case where the particle (or droplet) consists partially of $\mathrm{CaO}$ and partially of $\mathrm{CaCO}_{3}$. Thus, let $\mathrm{x}$ be the activity of $\mathrm{CaO}$ and $(1-\mathrm{x})$ be the activity of $\mathrm{CaCO}_{3}$, where $\mathrm{x}$ can be interpreted as the fraction of calcium carbonate that has decomposed.

Substituting into the previous equation,

$$
\mathrm{k}=\left(\mathrm{x} \cdot \mathrm{P}_{\mathrm{CO} 2}\right) /(1-\mathrm{x})
$$

and solving for $\mathrm{x}$ gives,

$$
\mathrm{x}=\mathrm{k} /\left(\mathrm{P}_{\mathrm{CO} 2}+\mathrm{k}\right)
$$

Knowing $\mathrm{k}$ as a function of temperature, we can find $\mathrm{x}$, the degree of decomposition of the calcium carbonate, if we know the partial pressure of the carbon dioxide in the atmosphere surrounding the particle.

At this point, we have already learned something: The result depends on the concentration of $\mathrm{CO}_{2}$ we assume for the gases surrounding the limestone particle. Late in the foaming process, we might expect the bubbles in the foam to be mostly filled with $\mathrm{CO}_{2}$ from the calcium carbonate decomposition, hence the $\mathrm{CO}_{2}$ concentration would be close to 100 per cent.

In the early stages of foaming, the situation should be quite different. Solid glass has a specific gravity of about 2.5 , whereas the powdered batch mixture (which is mostly glass) has a bulk specific gravity in the range of 0.6 to 0.8 before heating. This means that the batch mixture is at least $68 \%$ (by volume) void space.

As the batch mixture is heated and begins to melt, some consolidation occurs as the glass particles sinter together. Still, there is considerable void space within the batch. The limestone particles are initially surrounded by gases from the furnace interior, which have infiltrated the voids in the powdered batch mixture.

DIAL's laboratory ovens have air atmospheres. The volume fraction of carbon dioxide in the earth's atmosphere is 0.000314. [5] Hence, at sea level, the partial pressure of $\mathrm{CO}_{2}$ is 0.000314 atmospheres. Using this value for $\mathrm{P}_{\mathrm{CO} 2}$, and the tabulated values of $\mathrm{k}, \mathrm{x}$ was found as a function of temperature. 
This calculation was repeated using an ambient atmospheric pressure of 0.757 of a standard atmosphere, corresponding to an elevation of 7,500 feet. [6] (The $\mathrm{CO}_{2}$ partial pressure was $\mathrm{P}_{\mathrm{CO} 2}=0.757 \times 0.000314=0.000238$ standard atmospheres.)

Earthstone's furnaces are fired by natural gas. A stoichiometric mixture of natural gas and air will burn to produce a gas mixture with a $\mathrm{CO}_{2}$ mole fraction of about 0.095 . Hence, the partial pressure of $\mathrm{CO}_{2}$ will be 0.095 standard atmospheres at sea level, and $0.757 \times 0.095=0.0719$ standard atmospheres at 7,500 feet.

The calculation of $\mathrm{x}$, the degree of decomposition, as a function of temperature, was calculated for these four cases: Air atmosphere at sea level, air atmosphere at 7,500 feet, 9.5\% $\mathrm{CO}_{2}$ atmosphere at sea level, and 9.5\% $\mathrm{CO}_{2}$ atmosphere at 7,500 feet. Figure A1 shows the results of these calculations.

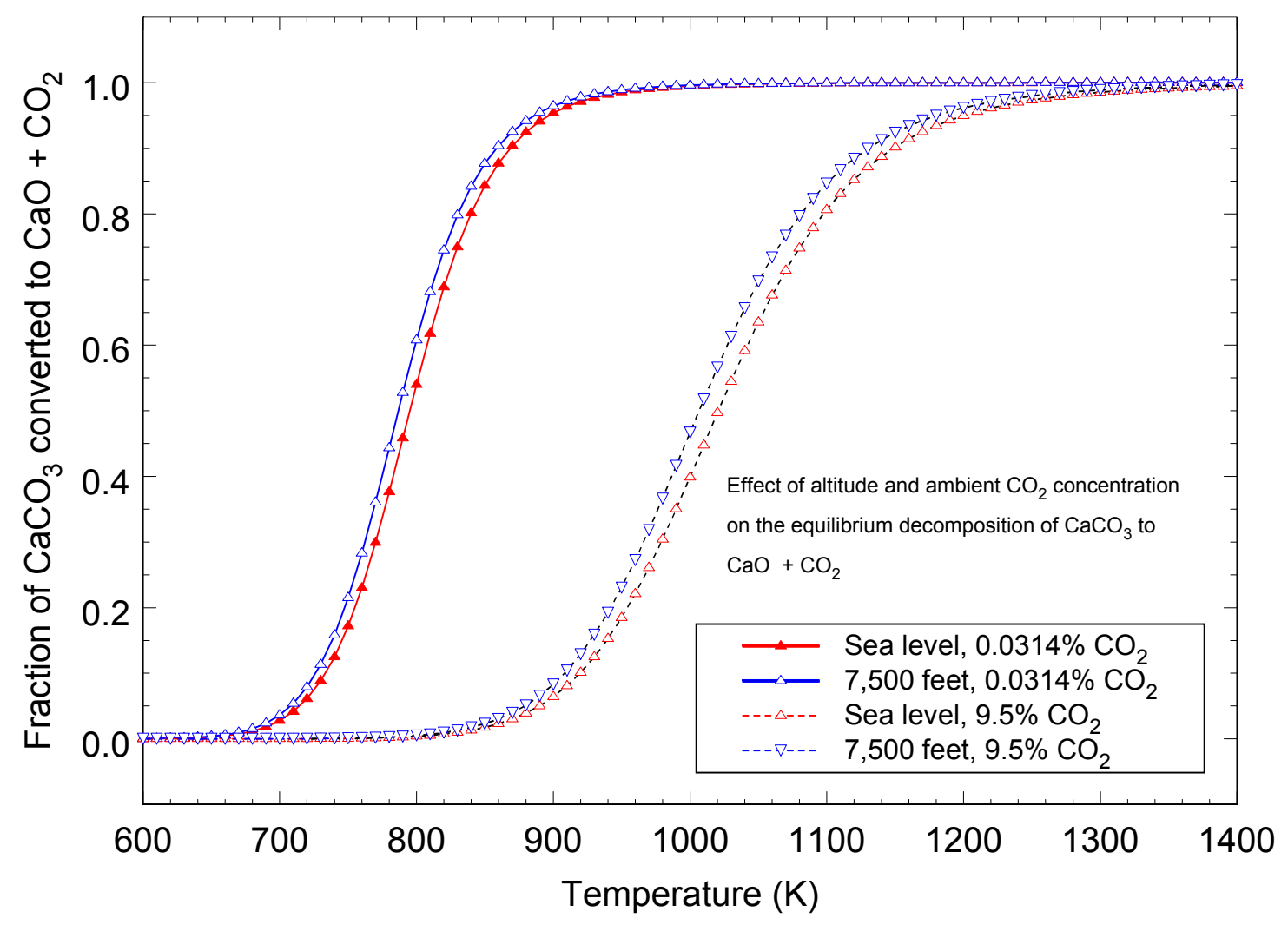

Figure A1. Results of equilibrium calculations for the decomposition of calcium carbonate into calcium oxide and carbon dioxide. Altitude has but a slight effect on the results, but the assumed concentration of $\mathrm{CO}_{2}$ has a major effect. 
Figure A1 clearly shows that the difference in altitude has but a small effect, but the difference in ambient $\mathrm{CO}_{2}$ concentration seems to make a large difference. By comparing this figure to the DSC results shown in Figure 1, it is seen that the actual decomposition lags considerably behind the degree of decomposition predicted by the equilibrium calculation. 